\title{
Grain Legumes and Fear of Salt Stress: Focus on Mechanisms and Management Strategies
}

\author{
Muhammad Nadeem ${ }^{1}$, Jiajia Li ${ }^{1}$, Muhammad Yahya ${ }^{2}$, Minghua Wang ${ }^{1}$, Asif Ali ${ }^{2}$, \\ Andong Cheng ${ }^{1}$, Xiaobo Wang ${ }^{1, *}$ and Chuanxi Ma ${ }^{1}$ \\ 1 School of Agronomy, Anhui Agricultural University, Hefei 230036, China; \\ rananadeem.aaur@yahoo.com (M.N.); lijia6862@ahau.edu.cn (J.L.); minghuawang.ahua@gmail.com (M.W.); \\ genetics08248@gmail.com (A.C.); machuanxi@ahau.edu.cn (C.M.) \\ 2 School of Life Sciences, Anhui Agricultural University, Hefei 230036, China; yahyapbg@gmail.com (M.Y.); \\ aligenetics08@gmail.com (A.A.) \\ * Correspondence: wangxiaobo@ahau.edu.cn; Tel.: +86-551-6578-6208
}

Received: 3 January 2019; Accepted: 11 February 2019; Published: 13 February 2019

check for updates

\begin{abstract}
Salinity is an ever-present major constraint and a major threat to legume crops, particularly in areas with irrigated agriculture. Legumes demonstrate high sensitivity, especially during vegetative and reproductive phases. This review gives an overview of legumes sensitivity to salt stress (SS) and mechanisms to cope with salinity stress under unfavorable conditions. It also focuses on the promising management approaches, i.e., agronomic practices, breeding approaches, and genome editing techniques to improve performance of legumes under SS. Now, the onus is on researchers to comprehend the plants physiological and molecular mechanisms, in addition to various responses as part of their stress tolerance strategy. Due to their ability to fix biological nitrogen, high protein contents, dietary fiber, and essential mineral contents, legumes have become a fascinating group of plants. There is an immense need to develop SS tolerant legume varieties to meet growing demand of protein worldwide. This review covering crucial areas ranging from effects, mechanisms, and management strategies, may elucidate further the ways to develop SS-tolerant varieties and to produce legume crops in unfavorable environments.
\end{abstract}

Keywords: legumes; salt stress; tolerance; genomics; speed breeding; CRISPR-cas9

\section{Introduction}

To meet the challenge of feeding a continuous growing population and there will be an urgent need to enhance productivity around $87 \%$ or even more of what we are producing at present especially cereals and legumes by 2050 [1]. However, major abiotic constraints, which includes drought, heat, cold, and salinity critically threatens productivity and causes major yield loss in large areas [2-4]. Among these, salt stress (SS) is one of the major constraint to profitable crop production [5] and is likely to increase due to environmental changes and as a result of various irrigation malpractices. SS negatively influences 60 million hectares, or round about $20 \%$ of the total irrigated land area in the world [6]. Salinity can be termed as abiotic stress and comprises all the problems due to salts primarily by an abundance of sodium chloride $(\mathrm{NaCl})$ from irrigation or natural accumulation [7].

Legumes belong to family Fabaceae and are a nourishing and low-cost food. Legumes are an excellent source of proteins and edible oil and can play a significant role in meeting food and oil needs in the present situation of global climate change. Legume crops also are a major source of carbohydrates, isoflavones vitamins, fiber, and minerals for human and animals. Crop rotation that comprises legumes is an effective approach to replenish fertility of the soil and enhances yields due to 
the nitrogen fixation [8]. Worldwide grain legumes occupy $12-15 \%$ of arable land to provide $33 \%$ of dietary protein and produce $27 \%$ of major crop production [9].

In legumes, salinity effects overall plant growth and development [10,11], by disturbing the nutritional imbalances, the complex interaction of hormones, osmotic effects and specific ion toxicity [12,13]. SS also disturbs composition of grains and grain yield [14,15]. For instance, increased necrosis and chlorosis of leaves observed under salinity, which leads to leaf senescence and decrease in photosynthesis in grain legumes $[16,17]$. The influence of salinity stress on several other crops has been previously reviewed $[18,19]$, but no comprehensive study is available on the sensitivity, mechanisms, and approaches of salinity stress tolerance in legume crops. Our review about effects, mechanisms, and management strategies may lead to the development of salt-tolerant cultivars under SS.

\section{Legumes Sensitivity to Salt Stress (SS)}

Salinity has devastating impacts on plants by affecting germination and growth, reproductive stage, and the ability to biological nitrogen fixation in grain legumes [20]. Salinity affects vital physiological functions, nutritional imbalances, and hormonal regulation [21,22], reduced carbon fixation [10], flower abortion, and reduced numbers of flowers and pod set, and eventually impedes crop production [17]. Salinity is becoming one of the main threat to crop productivity and has an inimical impact on plants (Figure 1).

Under SS, plant growth is affected at two phases; early phase (osmotic phase) and late phase (ionic phase) [23]. The early response of plants under saline conditions is due to the salt outside the root zone whereas SS at the late phase is the consequence of the toxic effect of salt accumulation inside the plant [24]. Seed germination is a critical stage during the plant life-cycle. Salinity affects seed germination by the toxic effect of ions on the seed embryo and inhibiting the water uptake [25]. Shu et al. [26] reported that SS inhibits soybean seed germination by decreasing the gibberellin (GA)/abscisic acid (ABA) ratio. Kumar et al. [27] reported that salinity reduces germination and seedling growth of soybean. Ma et al. [28] observed that $\mathrm{NaCl}$ negatively affects seed germination in alfalfa. Haileselasie and Teferii, [29] found that SS severely affects germination and growth of chickpea. Similarly, the $50 \%$ reduction in seed germination observed due to the increasing level of salinity from 0-180 $\mathrm{mM} \mathrm{NaCl}$ in Phaseolus vulgaris L. [30].

In legumes, higher sensitivity to SS is observed during seedling and developmental stages than the germination stage [31]. Salinity limits the growth of several legumes, including mungbean [32], soybean [33], lentil [34], and faba bean [35]. These growth limitations are often attributed to the decline in water potential of tissue, indicating less availability of water to cells [36], which results in closure of stomata, declined photosynthesis, and inhibited growth [37]. The chlorophyll content, as an indicator of photosynthetic activity, normally reduced under salinity in soybean plant [38]. Ning et al. [39] reported decline in photosynthesis and growth of soybean under salinity. A salinity-induced decline in photosynthesis is not only as a result of stomatal limitations, but also due to non-stomatal factors including reduced photosynthetic pigments, chlorophyll fluorescence, and ultrastructural damage [40,41]. The reduced plant growth under salinity is often associated with reduced photosynthetic activity [42]. Zawude and Shanko, [43] found that chickpea is sensitive to SS, particularly during the period of early stages of growth and development. Demir and Arif, [44] drew attention to the fact that salinity adversely affected root length compared to shoot length.

Salinity affects the competitive nutrient uptake, accumulation, and transport in plants. Under salinity, the abundance of $\mathrm{Na}^{+}$and $\mathrm{Cl}^{-}$ions concentrations in the rhizosphere will cause nutritional imbalance in plants as these ions interfere with other nutrients, including nitrogen $(\mathrm{N})$, phosphorus $(\mathrm{P})$, potassium $(\mathrm{K})$, boron $(\mathrm{B})$, calcium $(\mathrm{Ca})$, zinc $(\mathrm{Zn})$, copper $(\mathrm{Cu})$, magnesium $(\mathrm{Mg})$, and iron $(\mathrm{Fe})[21,22,45]$. Previous investigations have confirmed that the harmful effects of SS on the plant may occur through an ionic imbalance, particularly of $\mathrm{K}^{+}$and $\mathrm{Ca}^{2+}$. According to Greenway and Munns, [46], plants must maintain relatively higher concentrations of $\mathrm{K}^{+}$and $\mathrm{Ca}^{2+}$ if they are to survive successfully under SS environment. Higher salt contents decrease the concentrations of $\mathrm{Ca}^{2+}, \mathrm{K}^{+}, \mathrm{Mg}^{2+}$ and other cations, 
which play a vital role in the photosynthetic activity of plant [47]. For instance, a significant reduction of $\mathrm{Na}^{+} / \mathrm{K}^{+}$ratio observed in mungbean [48], and chickpea [36], due to competitive uptake of $\mathrm{Na}^{+}$and $\mathrm{K}^{+}$ion flux, resulting in deficiency of $\mathrm{K}^{+}$and significant yield losses [49]. In soybean, salinity stress reduced the accumulation of $\mathrm{Ca}^{2+}, \mathrm{K}^{+}$, and $\mathrm{Mg}^{2+}$ in the leaves [50]. In addition, SS has an adverse impact on nodulation and final yield. Early studies uncovered that SS interferes with $\mathrm{N}$ uptake and biological $\mathrm{N}$ fixation, which limits $\mathrm{N}$ supply in legumes [51]. Nodules are responsible for $\mathrm{N}$ fixation in legumes; however, the mechanism of nodulation is extremely sensitive to SS. For instance, previous studies revealed that SS substantially affect the activity and density of nodules in pigeon pea [15] and faba bean [51,52] and leads to premature nodules senescence [53]. Legumes are highly sensitive to SS which leads to sever yield losses (Table 1). Khan et al. [54] reported a significant reduction in yield and yield-related traits (number of pods and seed weight) under SS in soybean. Similarly, Ghassemi-Golezani et al. [55] noted that all yield-related traits were equally responsible for final yield reduction under SS in soybean. In the case of chickpea, SS-induced a decrease in final yield due to shriveled seeds and a reduction in grain weight by $20 \%$ [56,57]. Ahmed, [58] observed fewer grains per pod and lower grain weight under salinity stress in mungbean. Recently, Farooq and coworkers review the diverse effects of SS on legume yield. They reviewed that SS leads to yield losses $(12-100 \%)$ in various legumes [59]. More importantly, a growing number of reports showed that SS adversely affects the composition and quality of grain legumes [15]. For instance, SS significantly reduced protein contents in mungbean, chickpea, and faba bean due to a decline in $\mathrm{NO}_{3}$ supply from the soil $[52,55,60]$. In soybean, SS affects grain oil and protein contents; the protein and oil contents decreased with increasing salt concentrations compared with control [55]. It has been reported that higher concentrations of salt decreased the amino acid, carbohydrates, polysaccharides, and protein contents in grains of mungbean [61]. In conclusion, salinity disturbs overall plant growth in legumes by influencing seed germination, photosynthesis, nutrient uptake and nutritional imbalance, and final yield.

Table 1. Yield reduction under different salinity levels.

\begin{tabular}{cccc}
\hline Legume Crops & Salt Concentration & Yield Loss (\%) & Reference \\
\hline Soybean (Galarsum) & $14.4 \mathrm{dSm}^{-1}$ & $50 \%$ & {$[54]$} \\
\hline Soybean (Lee) & $8.5 \mathrm{dSm}^{-1}$ & $53 \%$ & {$[50]$} \\
\hline Soybean (loam soil) & $7 \mathrm{dSm}^{-1}$ & $46 \%$ & {$[20]$} \\
\hline Soybean (caly soil) & $6.3 \mathrm{dSm}^{-1}$ & $46 \%$ & {$[62]$} \\
\hline Mungbean (cv. Pusavishal) & $50 \mathrm{mM} \mathrm{NaCl}^{-1}$ & $41 \%$ & {$[32]$} \\
\hline Mungbean (var. 245/7) & $8 \mathrm{dSm}^{-1}$ & $60 \%$ & {$[58]$} \\
\hline Mungbean (var. NM-51) & $12 \mathrm{dSm}^{-1}$ & $77 \%$ & {$[58]$} \\
\hline Mungbean (var. NM-92) & $8 \mathrm{dSm}^{-1}$ & $61 \%$ & {$[58]$} \\
\hline Mungbean (var. 6601) & $12 \mathrm{dSm}^{-1}$ & $72 \%$ & {$[58]$} \\
\hline Chickpea (var. FLIP 87-59) & $3.8 \mathrm{dSm}^{-1}$ & $69 \%$ & {$[62]$} \\
\hline Chickpea (var. FLIP 87-59) & $2.5 \mathrm{dSm}^{-1}$ & $43 \%$ & {$[20]$} \\
\hline Chickpea (var. ILC 3279) & $3.8 \mathrm{dSm}^{-1}$ & $72 \%$ & {$[62]$} \\
\hline Fababean (loam soil) & $6.6 \mathrm{dSm}^{-1}$ & $50 \%$ & {$[62]$} \\
\hline Fababean (clay soil) & $5.6 \mathrm{dSm}^{-1}$ & $52 \%$ & {$[20]$} \\
\hline Fababean (loam soil) & $4.9 \mathrm{dSm}^{-1}$ & $28 \%$ & {$[20]$} \\
\hline Fababean (clay soil) & $4.3 \mathrm{dSm}^{-1}$ & $19 \%$ & {$[20]$} \\
\hline Lentil (cv. 6796) & $3.1 \mathrm{dSm}^{-1}$ & $100 \%$ & {$[20]$} \\
\hline Lentil (cv. 6796) & $2 \mathrm{dSm}^{-1}$ & $14 \%$ & $24 \%$ \\
\hline Lentil (cv. 5582) & $2 \mathrm{dSm}^{-1}$ & $88 \%$ & \\
\hline Lentil (cv. 5582) & $3.1 \mathrm{dSm}^{-1}$ & & {[} \\
\hline
\end{tabular}




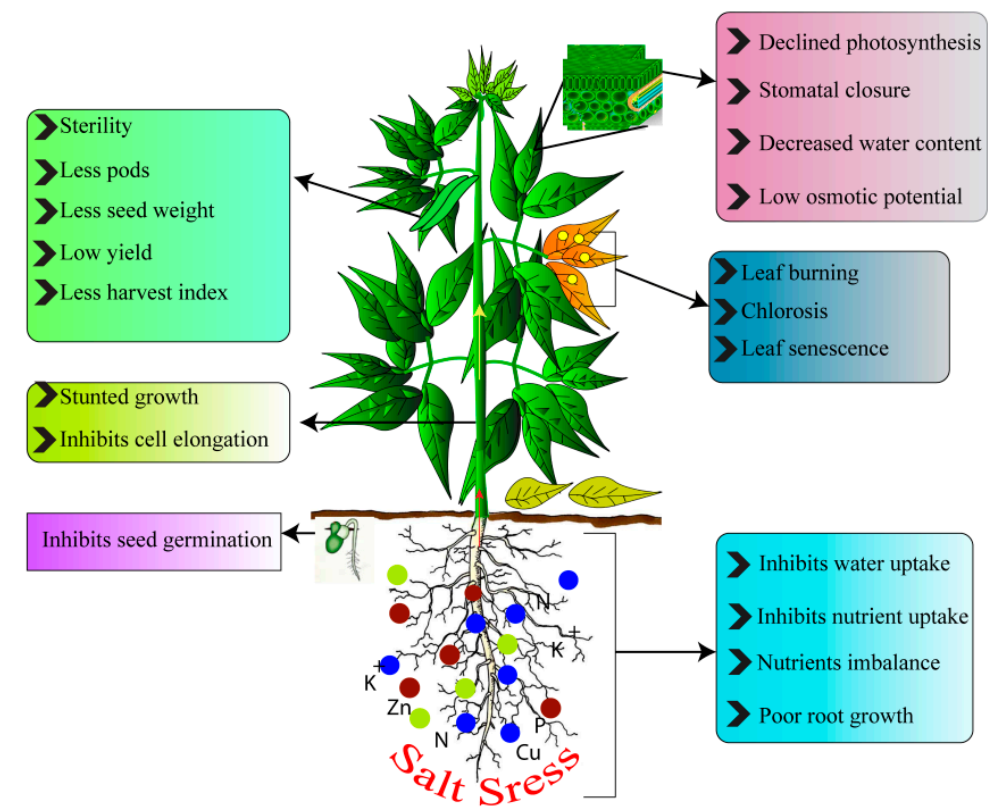

Figure 1. Schematic representation of plant response to salt stress (SS).

\section{Tolerance Mechanisms}

To increase the yield of legumes under SS, it is imperative to first understand tolerance mechanisms. Plants are evolved with different adaptations including ion homeostasis, compatible solute accumulation and osmotic protection, antioxidant regulation, and hormonal regulation. Research advances elucidating these mechanisms are discussed below.

\subsection{Ion Homeostasis and Salt Tolerance}

In plants, ion homeostasis is an imperative mechanism of cells under SS. It helps to maintain lower concentrations of $\mathrm{Na}^{+}$and higher concentrations of important ion $\mathrm{K}^{+}[25,63]$. Ion flux regulation of intracellular $\mathrm{Na}^{+}$and $\mathrm{K}^{+}$is fundamental for the activities of different enzymes in the cytosol as well as for the regulation of cell volume and maintenance of membrane potential [63]. Under SS, plants eliminate unnecessary salts from the cytosol by primary active transport along with secondary transport to maintain the cytosolic levels of $\mathrm{Na}^{+}$and $\mathrm{K}^{+}[63,64]$. Under salinity, to sustain ion homeostasis plant cell regulate these cation transporters in the tonoplast and plasma membranes [64].

The $\mathrm{Na}^{+}$compartmentalization or exclusion from vacuole, providing a fundamental feature to avoiding the lethal effects of $\mathrm{Na}^{+}$in the cytosol of the cell [64]. Variation in ions distribution exists between species and cultivars of legumes, particularly the ratio of $\mathrm{K}^{+} / \mathrm{Na}^{+}$in the cytosol [52]. For instance, Mishra et al. [9] reported that the mash bean cultivar (T-44) has unique $\mathrm{K}^{+} / \mathrm{Na}^{+}$ transporters which assist in maintaining lower level of intracellular $\mathrm{Na}^{+}$. While in pigeon pea, Subbarao et al. [65] reported a decreased $\mathrm{Na}^{+} / \mathrm{Ca}^{2+}$ ratio under salinity regulates the uptake of $\mathrm{K}^{+}$which leads to improve $\mathrm{Na}^{+} / \mathrm{K}^{+}$ratio. It has been observed that a mechanism for salinity tolerance comprises exclusion of $\mathrm{Na}^{+}$and $\mathrm{Cl}^{-}$from shoots, maintenance of higher $\mathrm{Na}^{+} / \mathrm{K}^{+}$ratio in the shoots, and increased uptake of $\mathrm{K}^{+}$in pigeon pea [66]. The ion sequestration in older tissues and the elimination of $\mathrm{Na}^{+}$and $\mathrm{Cl}^{-}$through roots may help to protect younger leaves and reproductive organs [23]. Turner et al. [67] observed that SS in chickpea is associated with high concentrations of $\mathrm{Na}^{+}$in seeds and young leaves, but in older tissues, no association was found. Under salinity, exclusion of $\mathrm{Na}^{+}$ from the transpiration stream into the xylem by exchange with $\mathrm{K}^{+}$at the xylem/symplast boundary of the roots [68]. The exchange is assisted by antiporters $\left(\mathrm{K}^{+} / \mathrm{H}^{+}\right.$and $\left.\mathrm{Na}^{+} / \mathrm{H}^{+}\right)$, boosted by $\mathrm{H}^{+}$-ATPase, dependent on anion permeability, and further boosted by higher concentrations of apoplastic $\mathrm{K}^{+}$[69]. 
In soybean, the activity of $\mathrm{H}^{+}$-PPase and $\mathrm{H}^{+}$-ATPase in the tonoplast of salt-tolerant cultivar improved under salinity, relative to a sensitive cultivar [70].

Increasing evidence revealed the role of a salt overly sensitive (SOS) pathway in ion homeostasis and salt tolerance $[63,71]$. The SOS pathway comprises of three noteworthy proteins, SOS1, SOS2, and SOS3 (Figure 2). The SOS1 encodes $\mathrm{Na}^{+} / \mathrm{H}^{+}$antiporter and is essential in regulating $\mathrm{Na}^{+}$efflux at the cellular level. It also assists in the movement of $\mathrm{Na}^{+}$from root to shoot in the plant. Overexpression of SOS1 improves salt tolerance in plants [72]. The antiporter SOS1 assists in the removal of excessive $\mathrm{Na}^{+}$ from roots and involves long-distance $\mathrm{Na}^{+}$transport in xylem. The SOS1 homolog has been observed in all crop plants and possibly plays a fundamental role in legumes under salinity [9]. The SOS2 encodes a serine/threonine-specific protein kinase, is stimulated by salinity stress elicited $\mathrm{Ca}^{2+}$ signals. The SOS2 comprises of a C-terminal regulatory domain and an $\mathrm{N}$-terminal catalytic domain [73]. The SOS3 protein is a myristoylated $\mathrm{Ca}^{+}$binding protein and has a myristoylation site at $\mathrm{N}$-terminus. This myristoylation site plays a fundamental role in regulating salinity tolerance [74]. In conclusion, the removal of excess $\mathrm{Na}^{+}$and $\mathrm{Cl}^{-}$ions and their compartmentalization into old tissues or vacuoles, is an important feature for salinity stress tolerance.

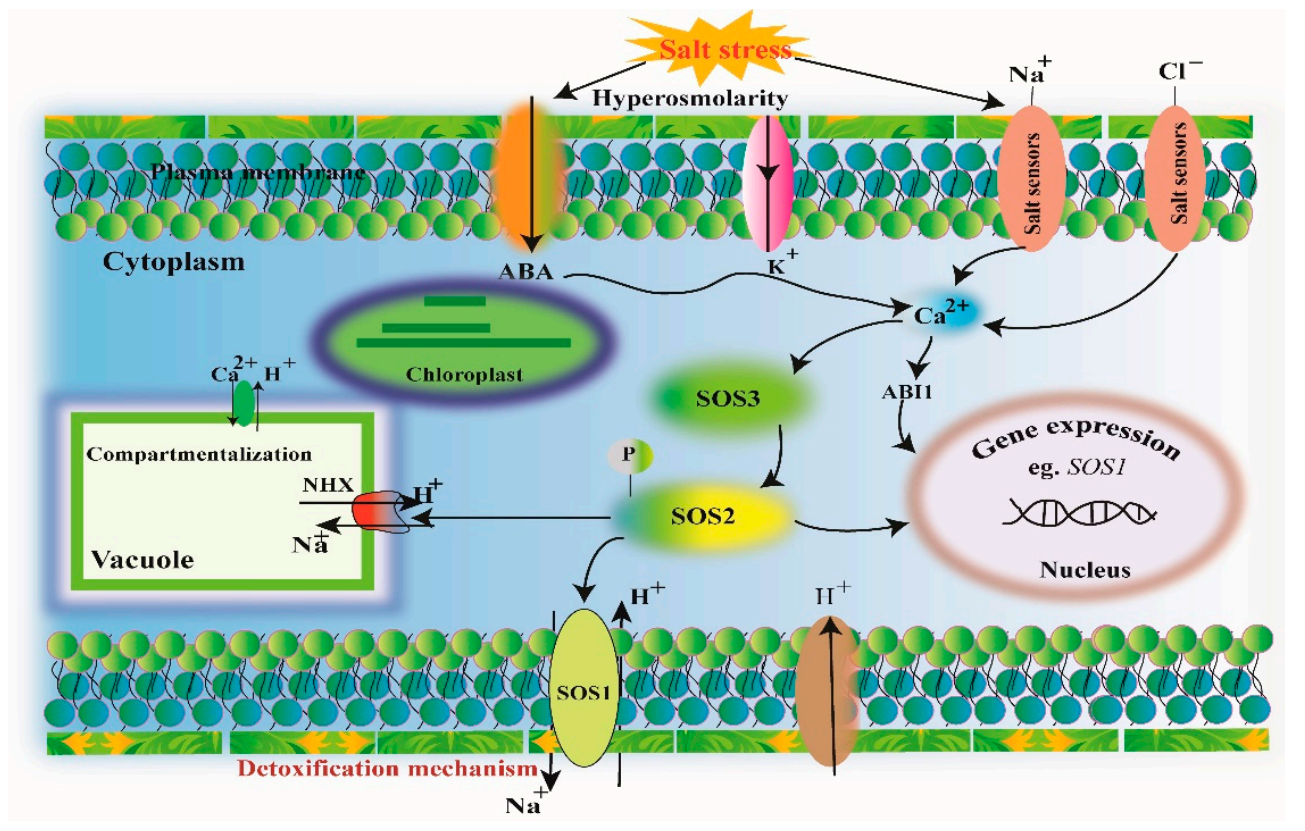

Figure 2. Schematic representation of the salt overly sensitive (SOS) pathway for salinity stress response. The SOS pathway regulates the $\mathrm{Na}^{+} / \mathrm{H}^{+}$antiporters. The SS-induced increase in $\mathrm{Ca}^{2+}$ concentration in cytosol and is sensed by SOS3. SOS3 work together with SOS2 and triggers its kinase activity. The SOS2-SOS3 localized in plasma membrane. Then SOS2 phosphorylates SOS1 and triggers its antiporter $\left(\mathrm{Na}^{+} / \mathrm{H}^{+}\right)$activity assisting $\mathrm{Na}^{+}$efflux from plant cell.

\subsection{Compatible Solute Accumulation and Osmotic Protection}

To cope harmful osmotic effects during phase I of SS, crop plants adopt a fundamental strategy termed as osmoregulation [25]. In the process of osmoregulation, the cell water potential declines without any decrease in turgor. Osmotic stress adjustment occurs through uptake of ions and synthesis of solutes like polyols, sugars, amides, amino acids, quaternary ammonium compounds and proteins [75]. Organic solutes and inorganic ions are involved in osmotic stress adjustment in the plant under SS, but their comparative functions are different between genotypes and species. The solutes which are not toxic even at higher concentration and involved in osmotic adjustment are called compatible solutes. These compatible solutes are hydrophilic compounds with low molecular weight and no net charge at physiological pH and also termed as osmoprotectants [68]. El Sayed [22] observed that salt-tolerant bean plants had less protein and high proline and amino acids contents than 
a salt-sensitive broad bean. Similarly, salt-tolerant mash bean and faba bean had higher concentrations of leaf proline under salt stress than the control [52,76]. Additionally, pigeon pea and mungbean accumulated more glycine betaine (GB) under salinity [75,77]. In chickpea, proline, soluble sugars, choline, and GB accumulation helped to maintain photosynthetic pigments and improved plant growth and development under salinity conditions [78]. In soybean, the regulation of trigonelline, proline, and potassium concentrations improve osmotic adjustment in plants [79]. Similarly, the accumulation of amino acids, reducing sugars, and ascorbic acid involved in the osmotic adjustment in pea plants under salt stress [80]. In conclusion, proline and GB are the key osmolytes involved in osmoregulation and diminish the effects of osmotic stress in grain legumes.

\subsection{Antioxidant Regulation of Salinity Tolerance}

Like other stresses, salinity stress might uncouple various metabolic pathways and several enzymes, which results in the accumulation of lethal and undesirable reactive oxygen species (ROS), such as hydrogen-peroxide $\left(\mathrm{H}_{2} \mathrm{O}_{2}\right)$, hydroxylradical $\left({ }^{\bullet} \mathrm{OH}\right)$, superoxide-radical $\left(\mathrm{O}_{2}{ }^{\bullet-}\right)$, and singlet-oxygen $\left(\mathrm{O}_{2}\right)$. These ROS damage cells, along with different proteins, nucleic acids, and membrane lipids, which lead to oxidative stress. Salt-tolerant legumes have an antioxidant defense system (Figure 3), to deal ROS by antioxidants activities [25]. Plants have a diverse array of non-enzymatic antioxidants, such as glutathione, carotenoids, tocopherols, ascorbic acid, flavonoids and flavones, and certain antioxidant enzymes, such as glutathione reductase (GR), glutathione peroxidases (GPX), ascorbate peroxidase (APX), superoxide dismutase (SOD), glutathione S-transferases (GST), monodehydroascorbate reductase (MDHAR), and catalase (CAT) to remove ROS $[81,82]$. Under salinity stress, it has been observed that the SOD, MDHAR, DHAR, GR, and APX activities increased in a salt-tolerant cultivar of pea [83]. Similarly, Yasara et al. [84] reported that SS enhanced APX and CAT activities in a salt-tolerant common bean cultivar (Gevas sirsk 57). In conclusion, increased antioxidant activities in legumes help to improve salinity tolerance by protecting from oxidative stress.

\subsection{Hormone Regulation of Salinity Tolerance}

Plant hormones (phytohormones) are chemicals that control and regulate all aspects of growth and development of plants. Major plant hormones are categorized into two categories growth promoters (gibberellins, cytokinins, and auxins) and growth retardants (ABA and ethylene). Under saline conditions, deviations in ABA and ethylene concentration are often observed. SS leads to the ABA up-regulation, which in turn elicits diverse adaptive responses in plants [85]. ABA pathway comprises the PYR, PYL, RCAR proteins complex, protein phosphatases 2C (PP2C), ABF transcription factors and SnRK2 protein kinases (Figure 3) [86]. In legumes, ABA is important for various stress responses, including metabolic changes, stomatal closure, and regulation of stress responsive genes. Enhanced concentration of $\mathrm{ABA}$ in other tissues and leaves not only disturbs stomatal activity but improves the production of stress proteins and salt adaptation by osmotic adjustment [87]. For instance, Lupinus albus L. closed stomata in response to ABA produced locally then to ABA synthesized by the roots and transported to leaves [88]. Under SS, the synthesis of ethylene and 1-aminocycloprane-1-carboxylic acid (ACC) precursor in nodules and roots activated senescence of leaves but was not associated with relatively better growth in faba bean and chickpea [82]. Thus, salinity changes the concentrations of hormones which induce alterations in osmotic adjustment, photosynthesis, and plant growth. 


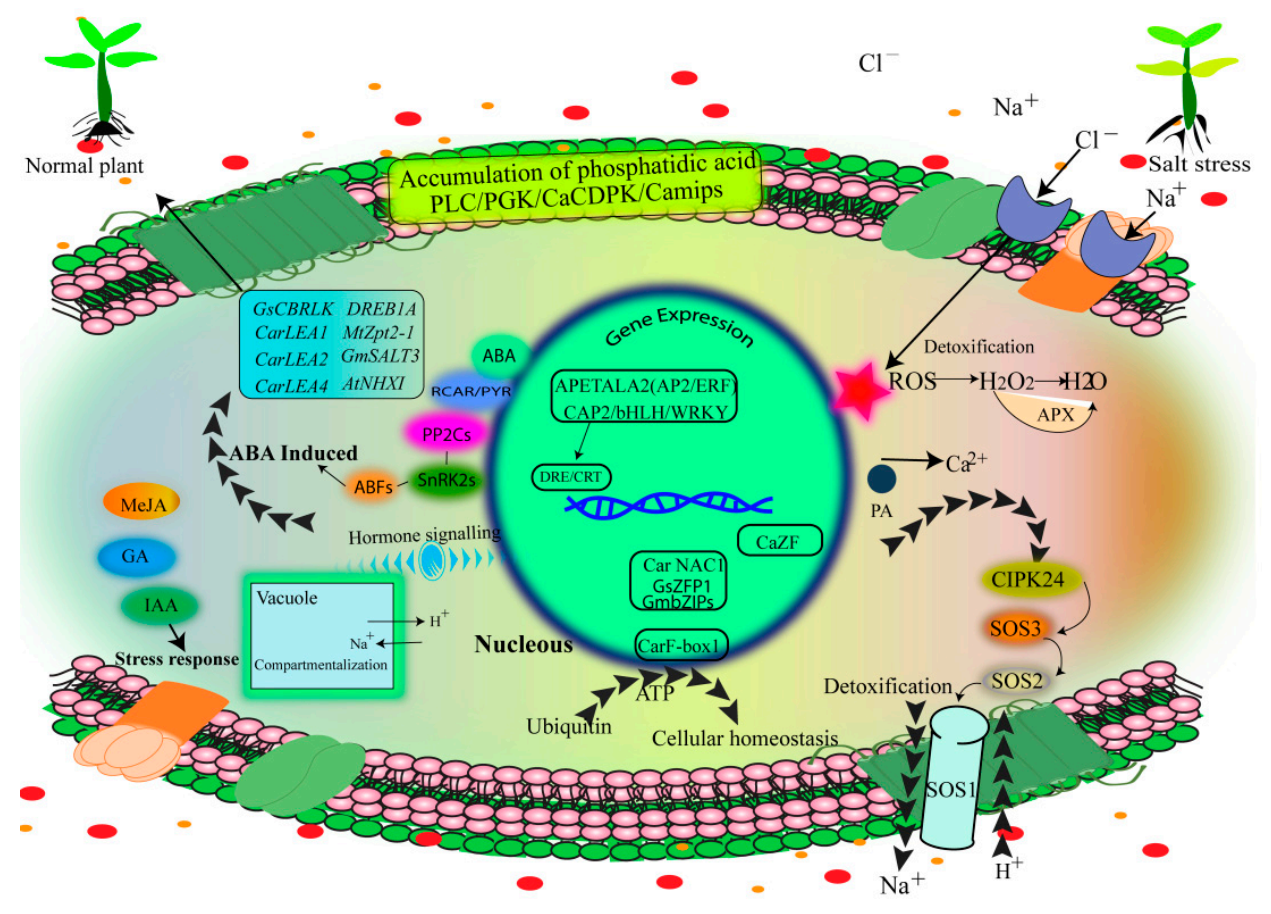

Figure 3. Schematic representation of salinity tolerance mechanism in Legumes. Reactive oxygen species (ROS), $\mathrm{Ca}^{2+}$ and ABA are activated under SS. SS induces synthesis of ABA, which, in turn, upregulates the transcription of ion transporter genes. Overexpression of transcription factors (GmbZIPs, GmNACs, GsZFP1, AP2/ERF, CarF box-1, and CarNAC, CAP2) have been reported under salinity.

\section{Management Strategies to Improve Salt Tolerance in Legumes}

Salt-tolerant plants grow and complete their life span on a substrate that comprises higher concentrations of soluble salt. Plants that can perform well on higher levels of salt in the rhizosphere and grow well are termed as halophytes. Salt tolerance is a complex trait comprising several interacting properties. To meet the challenge of feeding a continuous growing population, scientists and breeders are continuously looking for strategies to enhance crop productivity. The following sections will briefly review the strategies for improving SS tolerance of legumes under saline conditions.

\subsection{Agronomic Strategies to Reduce SS}

Salinity stress develops due to salt accumulation through soil chemical properties and irrigated water. Under saline conditions due to $\mathrm{Na}^{+}$and $\mathrm{Cl}^{-}$toxicity, the ratios of $\mathrm{Na}^{+} / \mathrm{Ca}^{2+}, \mathrm{Na}^{+} / \mathrm{K}^{+}$, $\mathrm{Cl}^{-} / \mathrm{NO}^{3-}$, and $\mathrm{Ca}^{2+} / \mathrm{Mg}^{2+}$ increased in the soil. The imbalance in ion concentration effects plant growth, yield, and metabolic and physiological components [89,90]. Legume growth can be managed and improved by adopting certain agronomic strategies (nutrient management and water management) and, thus, will improve plant growth, soil health, and input use efficiency under saline conditions.

\subsubsection{Reclamation of Salt-Affected Soils by Nutrients Management}

Under saline conditions, nutrients imbalance was observe due to $\mathrm{Na}^{+}$and $\mathrm{Cl}^{-}$toxicity and deficiency of major $\left(\mathrm{N}, \mathrm{P}, \mathrm{K}^{+}\right)$and minor $\left(\mathrm{Ca}^{2+}, \mathrm{S}, \mathrm{Mn}, \mathrm{Zn}^{2+}\right)$ nutrients in several crops [91,92]. Suitable fertilizer applications or nutrient management on crop plants is a very practical way for alleviating salt injury [93,94]. In order to manage nutrients in salt-affected soils, the main approach is the application of gypsum $\left(\mathrm{CaSO}_{4} \cdot 2 \mathrm{H}_{2} \mathrm{O}\right)$, which is a major source of $\mathrm{Ca}^{2+}$, to improve soil water infiltration and for reclamation of $\mathrm{Na}^{+}$toxic soil. Under saline conditions, application of $100 \% \mathrm{CaSO}_{4} \cdot 2 \mathrm{H}_{2} \mathrm{O}$, the combination of $\mathrm{H}_{2} \mathrm{SO}_{4}+$ farm yard manure $+\mathrm{CaSO}_{4} \cdot 2 \mathrm{H}_{2} \mathrm{O}, \mathrm{CaSO}_{4} \cdot 2 \mathrm{H}_{2} \mathrm{O}+$ chiseling + farm yard manure, humic acid (HA), and pyrite, have improved plant growth, soil properties, and yield in 
several crops [95,96]. Matuszak-Slamani et al. [97] reported that application of HA improves growth and development of soybean under saline soil environment. Lawson et al. [98] studied the effects of compost on growth and nodulation of the kidney bean, soybean, and alfalfa. They observed that growth and nodulation were improved by compost under saline conditions. Sun et al. [99] observed that biochar application to the saline soils can reduce $\mathrm{NH}_{3}$ volatilization, keep $\mathrm{N}$ retention, and decrease $\mathrm{N}$ leaching, which is beneficial for sustainable use of salt-affected soils. Additionally, exogenous osmoprotectants combined with compost will effectively solve salinity problem and are a good strategy to increase salinity resistance of soybean in the drylands [100]. In faba bean, soil organic matter improves plant growth due to the gradual release of certain nutrients in salt-affected soils [101]. Under low SS, the application of urea to N-deficient soil improved growth and productivity in chickpea [102]. Under mild saline conditions, enhancing $\mathrm{K}^{+}$concentrations improved growth, water relations, and productivity of mungbean [103]. Guo et al. [104] reported that increasing $\mathrm{NO}^{3-}$ supply for crop plants under SS can significantly reduce $\mathrm{Cl}^{-}$content and alleviate crop salt injury or enhance salt tolerance in soybean. It has been observed that the application of micronutrients improves growth and nutrient uptake either before or after the salinization treatment. The foliar application of micronutrients could induce an increase in SS tolerance in faba bean [105]. Similarly, it has been reported that foliar spraying with $\mathrm{Zn}$ or Fe chelate improves kidney bean SS tolerance, during early growth stages [106]. Exogenous application of $\mathrm{Si}$ mitigated the harmful effects of $\mathrm{Na}^{+}$and $\mathrm{Cl}^{-}$in common bean, cowpea, faba bean under saline conditions $[11,107,108]$. To mitigate the adverse effects of SS on the plant, we can also adopt some other agronomic approaches, such as subsoiling $(20-150 \mathrm{~cm}$ apart and $50+5 \mathrm{~cm}$ crosswise, furrows), sanding, use of fresh water, application of inorganic and organic fertilizers, and deep tillage [92,96]. In conclusion, the application of potash and nitrogenous fertilizers, and micronutrients foliar application may help to enhance growth and productivity under saline conditions.

\subsubsection{Reclamation of Salt-Affected Soils by Water Management}

Decline in yield depends on crop growth, concentrations of salts in irrigated water and soil, and climatic conditions. The approach used to eliminate soluble salts from rhizosphere is termed as the reclamation of saline soils. Reclamation of salt-affected soils for sustainable usage is a matter of great concern [99]. Irrigation water with higher $\mathrm{pH}$, residual sodium carbonate, sodium adsorption ratio, and high EC are also a reason for increased salinity stress and affect plant growth [109]. A better management approach is important to deal with salinity stress for better production. Irrigation water can be applied to maintain the salinity of soil at concentrations where higher yields can be obtained by applying excessive water to drain through the root zone and leach salts. We can apply canal water instead of underground water, if underground water is brackish. The availability of canal water is the better option to leach down salt from the root zone of crop plants. The application of soil ameliorants, such as $\mathrm{CaSO}_{4} \cdot 2 \mathrm{H}_{2} \mathrm{O}$, as a supplier of $\mathrm{Ca}^{2+}$ is the strategy for usage of unfit underground water because it improves soybean yield under saline conditions [110]. Gypsum amendment with unfit water is the best option if the availability of fit water is less than $25 \%$ [111]. It is reported that the application of $\mathrm{CaSO}_{4} \cdot 2 \mathrm{H}_{2} \mathrm{O}$ in composition with organic manure in salt-affected soils decreases the $\mathrm{pH}$, electrostatic precipitator (ESP) and EC, heavy metals, and soluble ions [112]. Liming of drainage water is also an effective strategy to reduce acidity-related constraints to increase productivity under SS [113].

\subsection{Plant Growth-Promoting Rhizobacteria}

The use of plant growth-promoting rhizobacteria (PGPR) is a useful strategy for avoiding the harmful effects of SS in legumes. In saline environments, improvement and development of salt-tolerant symbioses is important. Han and Lee [114] observed that PGPR improve photosynthesis, nutrient uptake, and growth in soybean grown under salinity. In common bean, the significant increase in shoot length was observed at salt concentrations 5.0, 7.5, and $10.0 \mathrm{dS} \mathrm{m}^{-1}$, when inoculated with Pseudomonas chlororaphis TSAU13 and P. extremorientalis TSAU20 [115]. It has been noted an increase 
in root and shoots growth in soybean and pea when inoculated with P. extremorientalis TSAU20 and P. trivialis 3Re27 under SS [116]. Soybean inoculation with Pseudomonas strains (P. putida TSAU1 and Bradyrhizobium japonicum USDA110) enhance root and shoot growth under saline environments [116]. The inoculation of soybean with arbuscular mycorrhizal fungi improves growth under SS [117]. Faba bean inoculation with Pseudomonas fluorescens, P. putida, and Bacillus subtilis improve growth under saline conditions [118]. Chaudhary and Sindhu [119] observed improvement in nodulation and plant biomass under SS, when inoculated with rhizobacterial and $\mathrm{ACC}^{+}$Mesorhizobium in chickpea.

Under saline conditions, PGPR can improve legumes symbiosis with Rhizobium spp. [120,121]. The P. extremorientalis TSAU20 and P. trivialis 3Re27 strains improve salt tolerance in Galaga officinalis L. The combined application of Pseudomonas and Rhizobium strains can enhance the yield of mungbean [122]. Similarly, the combined application of PGPR and Rhizobium spp. improve seedling growth, nodulation, and improve osmotic stress in mungbean under salinity [123,124]. PGPR can use a number of mechanisms to improve plant growth such as producing antifungal metabolites, phytohormones, lytic enzymes, reducing ethylene production, increasing nutrient uptake, and inducing systemic resistance in plants $[125,126]$. In conclusion, PGPR can improve plant growth by maintaining osmoregulation, improving photosynthesis, improving nodulation, and root growth for better water and nutrient uptake, and producing phytohormones under saline conditions.

\subsection{Seed Priming}

In grain legumes, two stages, seed germination and seedling development, are critical for the establishment and most sensitive to salinity stress. Previously, a growing number of reports studied the effects of seed priming under salt stress conditions. Seed priming is a controlled hydration process that is followed by redrying and activates many of the physiological processes associated with the early phase of germination and prepares the seed for radicle protrusion [127]. Furthermore, it can decline the physical resistance of the endosperm during imbibition and repair membranes but also lead to the development of immature embryos and leach emergence inhibitors [128]. Generally, several seed priming techniques, which include osmopriming, hydropriming, chemical priming, hormonal-priming, nutrient priming, and redox priming, are adapted to induce pre-germination changes $[127,129]$. In a most recent report, Dai et al. [130] observed that priming with $\mathrm{CaCl}_{2}, \mathrm{ZnSO}_{4}$, $\mathrm{GA}_{3}$, and betaine hydrochloride to improve salt tolerance in soybeans seedlings. Harris et al. [131] reported that seed priming with $\mathrm{ZnSO}_{4}$ enhance grain yield in chickpea. It has been observed that priming with Gibberellins can enhance seed germination and improve salt tolerance of alfalfa by improving antioxidant activities and reducing membrane damage [132]. Azooz [133] observed that priming with salicylic acid enhance salinity tolerance in two faba bean genotypes. Halopriming improves salt tolerance in mungbean [134] and chickpea [135]. Hydropriming improves seedling growth, and shoot and root biomasses compared with controls [130]. Ahmadvand et al. [136] observed that seed priming with potassium nitrate enhance germination, plant height, and plant dry weight in soybean. Khomari et al. [137] reported that biopriming with Trichoderma harzianum improve emergence rate of seedlings, and root and shoot length in soybean. Seed priming with $\mathrm{KNO}_{3}$ can be improved physiological characteristic and yield in chickpea [138].

\subsection{Role of Polyamines in Salinity Tolerance}

Polyamines have relatively low molecular weight, aliphatic polycations that are widely distributed in all living organism from unicellular to multicellular organisms [139]. Three main polyamines in plant species namely: putrescine, spermidine, and spermine, even though other kinds of polyamines can also be seen in plants, for instance, cadaverine. Polyamines' biosynthetic pathways have been studied by various researchers $[140,141]$. They are involved deliberately in a range of plant mechanisms, linked to plant growth and development process, for example, embryonic competence [142], fruit ripening [143], programmed cell death [144], and xylem differentiation [145]. Mounting evidence regarding polyamines suggests that they also have appropriate adaptive functional response under 
abiotic stresses and this is acclaimed by the considerable variation behavior in PA levels during stress. This variability in polyamine had been seemed in a number of plant species that were subjected to complex abiotic condition comprised of drought, salinity, low temperature, and low nutrient deficiency. Gu-wen et al. [146] reported that putrecine plays positive role in salinity tolerance through decreasing oxidative damage in soybean (Glycine max. L.). Similarly, Sheokand et al. [147] observed that the application of putrecine helps in scavenging superoxide radical as it enhanced the activity of SOD under salinity stress in chickpea. In faba bean, Suleiman [148] reported that application of putrecine regulates ion distribution in shoot and root. The application of spermidine and spermine helps to alleviate the lethal effects of salt stress and improve salinity tolerance in faba bean [149]. Radhakrishnan et al. [150] reported that the addition of spermidine significantly ameliorated the devastating effects of osmotic stress by regulating the level of plant hormones and antioxidants. In a most recent study in alfalfa, the exogenous application of sperimidine positively alleviates SS-induced damage [151]. Nahar et al. [152] reported that exogenous application of polyamines maintained nutrient homeostasis and reduced cellular Na content as well as regulated endogeneous polyamine concentrations in mungbean under salinity stress. In another study, the application of spermine confers salt tolerance in mungbean [153].

\subsection{Selection and Conventional Breeding Approaches}

In the case of complex polygenic traits, like tolerance to salinity, bulk and recurrent selection is adopted in order to increase the frequency of minor genes with an additive effect. From both physiological and genetic aspects, SS tolerance is a complex trait. In legume crops, economically feasible screening approaches for SS tolerance are lacking. In order to develop legumes with SS tolerance, an integrated approach comprising using existing genetic variation, exploiting diverse and novel sources to create new variations, and using breeding strategies with several traits instead of a single trait may be effective [154-156]. In legumes, mass screening is frequently adopted to select salt-tolerant germplasm to develop better performing legume genotypes. Sehrawat et al. [156] reported 117 genotypes of mungbean for SS tolerance and noted decreased seed germination and seedling growth in all 117 genotypes, but all 117 genotypes performed differently under SS and were categorized as moderately tolerant, highly tolerant, tolerant, highly susceptible, moderately susceptible, and susceptible genotypes. To screen for SS tolerance various traits/characters have been used such as seedling emergence, leaf soluble proline, leaf $\mathrm{Ca}^{2+} / \mathrm{Na}^{+}$, and $\mathrm{K}^{+} / \mathrm{Na}^{+}$ratio, stomatal conductance, photosynthetic activity, nodulation, osmotic adjustment, pods per plant, and yield. To screen genotypes for salinity stress tolerance, ion homeostasis is another important trait being used; however, the involvement of individual $\mathrm{Cl}^{-}$or $\mathrm{Na}^{+}$exclusion to SS tolerance has not been confirmed in certain legumes, like chickpea [23].

The accumulation of $\mathrm{Cl}^{-}$and $\mathrm{Na}^{+}$to lethal concentrations in the reproduction phase in legumes (Cicer arietinum L.) made it a highly sensitive phase to salinity [18]. However, no correlation was observed among $\mathrm{Na}^{+}$accumulation in shoots and yield due to SS in chickpea [57]. It appears that for legume crops like chickpea, a combination of mechanisms, e.g., tissue tolerance of excess ions and ion exclusion, plays an important role under saline conditions. However, in mungbean, breeding approaches need to comprise diverse background parental lines to produce genetically engineered salt-tolerant genotypes [16]. Since the ultimate aim for SS tolerance is yield under stress, the traits/characters used for evaluating SS tolerance must be correlated with yield [18] or genotypes selected for yield under saline conditions. To develop salt-tolerant genotypes of legumes, direct selection has been conducted at several locations [157]. For salinity tolerance, mass screening can be achieved on the basis of osmotic adjustment, homeostasis, plant biomass, and grain yield under saline conditions.

It has been known for decades that salinity stress appears to be a polygenic and quantitative trait in nature and regulated by several genes under diverse environments [158]. In order to improve understanding about salinity stress on a genetic basis, significant efforts have been made to identify different quantitative trait loci (QTL). The adoption of genomic and genetic analysis in several crops to 
identify DNA regions strongly associated with such quantitative traits, the molecular markers, to assist in breeding methods [159]. Moreover, an increasing number of previously published reports suggested the essential role of these markers for the indirect screening of improved crops speed up the screening process by alleviating laborious and time-consuming of direct selection in field and greenhouse. Previous studies also reported that DNA markers, simple sequence repeats (SSR), restriction fragment length polymorphism (RLFP), random amplification of polymorphic DNA (RAPD), and amplified fragment length polymorphism (ALFP) for abiotic stress [160]. In C. arietinum, various SSRs were identified to have a strong linkage with both seed yield under salt stress and control conditions [57]. An attempt to map QTL for SS tolerance, by using recombinant inbred lines (RIL) from a cross among salt-tolerant JG62 and salt-sensitive ICCV2 chickpea lines, identified grain yield varying during salinity, with a number of grains being the most closely related trait to yield [161]. A number of QTL were reported for grain yield and yield components during salt stress within each phenology group, but no major QTL was found when an analysis was made on the whole RIL population. The recent advance in genome-based approaches have endorsed the development of high-throughput approaches for genotyping, allowing the finding and accessing desirable alleles, different QTL having the potential to affect desired responses. In field pea, single nucleotide polymorphism (SNP) markers associated with expressed sequence tags (ESTs) were developed and used to generate comprehensive linkage maps for field pea [162]. They reported that out of 768 variant nucleotide positions screened for genotyping of RIL population, a total of 705 SNPs successfully detected segregating polymorphisms. More importantly, identifying new QTL plays a key role in crop improvement through marker-assisted selection (MAS). Furthermore, many breeding methodologies have been applying in the improvement of salt resistance in grain legumes based on MAS. MAS are often used to separate desirable QTL by mapping, to identify linkage drag correlated with undesirable alleles linked to target genes. A growing number of reports showed that salt tolerance is controlled by a minor QTL in chickpea [163], two minor QTL in field pea [162], single major QTL in soybean [160] and several minor QTL in Medicago truncatula [162]. In a most recent study, Shi et al. [164] identified a major salt tolerant QTL, which was flanked by SSRs Barcsoyssr_03_1421 and GMABAB on chromosome 3 in soybean, single trait composite interval mapping, based on single-marker regression, and multiple interval mapping analysis. A recent report has showed that QTL mapping for SS resistance in a Vigna species, cowpea known to be halophytic in nature [165]. Chankaew and co-workers built a genetic map, consisting of 150 SSRs, from F2 population derived from a cross among V. marina subsp and V. luteola. Evaluation of $\mathrm{F}_{2: 3}$ populations for salinity tolerance in hydroponic conditions at seedling and developmental stages, and segregation analysis showed that salinity tolerance in $V$. marina is regulated by a less number of genes. Approximately $50 \%$ phenotypic variation could be explained by multiple interval mapping which has regularly identified one major QTL. The flanking markers may assist to transfer allele that has tolerance against salt from V. marina subsp. oblonga into related Vigna crops. However, by implementing the MAS breeding method, which has certain limitations in terms of unreliability, marker validation, hindrance in association, inaccessibility of marker variation among the population, linkage drag, and breeding incompatibility problems among species [166], there is an urgent need for alternative molecular breeding to minimize the drawbacks linked to MAS approach to pave the way to comprehensively understand the integration of functional, structural, and comparative genomics.

\subsection{Bioengineering and Functional Genomics}

In legume crops, SS-induced genes are well distributed all over the genomes. QTL identification of related traits/characters in combination with marker tagging has turned out to be an important medium for the pointed insertion of the required trait to the unadapted trait. In recent times, crop improvement through molecular marker has gained momentum, where whole-genome sequencing (WGS) has built a strong foundation of newly developed single-nucleotide polymorphism (SNP) markers, simple sequence repeats (SSRs), and next-generation sequencing (NGS) technology, enhancing its cost-effectiveness and efficiency. The capability of molecular markers to screen QTL has been 
explored to develop crop varieties with improve SS tolerance under saline conditions. Guan et al. [167] screened 58 soybean accessions with three DNA markers, Barcsoyssr-3-1306, Barcsoyssr-3-1310 and QS080465 (InDel marker), which co-segregated with the salt-tolerance locus, when crossing salt-tolerant (Tiefeng 8) and salt-sensitive (85-140) soybeans. Additionally, Lee and coworkers studied the association among the linked SSR markers (Sat-091 and Satt-237) and salt-tolerance QTL by tracing the pedigrees of FT-Abyara and S-100, the parents used in QTL mapping [160]. The DNA markers associated with QTL might be useful for marker-assisted selection to pyramid tolerance genes for both saline and alkaline stresses [168]. However, QTL mapping would be highly efficient and effective if linked genes along with the computational improvements were added to the analysis. Sehrawat and coworkers developed 38 SSRs (novel microsatellite markers) for the detection of genetic variations in 12 mungbean genotypes (nine cultivated and three wild) under salt stress [156]. The developed SSRs help to explore the genetic variations in mungbean cultivars having a narrow genetic base, as well as within related legume crops [169]. Marker index (MI) and high-resolution power (RP) further confirmed that these SSR markers are highly helpful. Therefore, the wild mungbean can be selected for the improvement of the genotypes for SS tolerance by broadening their genetic base. Assessment of the diversity among the examined genotypes would be of significance for designing breeding strategies for the improving quantitative trait alleviating SS tolerance [170]. The SSRs are very helpful in the identification of candidate genes or QTL capable of improving salinity tolerance. The SSRs associated to the genes/trait may assist for quick selection of genotypes rather than phenotypic screening in breeding programs [171]. Under drought stress, the addition of ABA or mi-RNAs accumulation has been studied in beans, but their function under saline conditions has not been investigated [172]. However, up-regulation of mi-RNAs play an important role in managing salinity stress in soybean [173].

Transferring genes from one crop to other crops to achieve required traits (qualitative or quantitative) is termed as the transgenic approach and this approach is very effective and efficient compared to conventional breeding. Several key SS-induced genes, including MiR172C, GmbZIP132, GmMYB177, GmMYB92, GmMYB76, and GmSALT3, have been reported, and their related mechanisms were studied [174-176]. Guan et al. [176] reported an SS-induced gene (GmSALT3) located on the chromosome 3 and has a dominant role in limiting $\mathrm{Na}^{+}$accumulation in leaves and shoots of soybean. Certain candidate genes for SS tolerance have been identified in legumes (Table 2). Neng et al. [39] reported that GmNHX1 and GmNcl1 might play important role in alleviating SS tolerance in soybean. Xue et al. [177] reported that overexpression of GmGMP1 conferring tolerance to high salinity stress during seed germination in soybean and Arabidopsis. Chen et al. [178] suggested that GmSK1 might play an important role to improve SS tolerance in plants. Li et al. [179] observed that overexpression of GmNAC15 in soybean hairy roots improve SS tolerance. An et al. [180] suggested that PgTIP1 is an SS tolerance associated gene involved in improving SS tolerance in transgenic soybean lines. Overexpression of GmBIN2 enhances SS tolerance in soybean and Arabidopsis [181]. The expression of $A t B 7, A t B F 3$, and $A t D R E B 2 A$ genes improves salinity tolerance through the accumulation of GB and proline in peanut [182]. Lopez et al. [183] observed that GB improves relative leaf water content and stomatal conductance in beans under SS. A number of genes have been successfully transferred into several species of legume to enhance SS tolerance by accumulating and synthesizing osmolytes, the uplifting activity of antioxidants, and improving sodium vacuolar sequestration. MtZpt2-1 is an SS tolerance associated gene involved in improving SS tolerance recovery of root growth and the development of root nodules after the salinity stress [184]. Additionally, the PR10a gene played a vital role in alleviating salinity tolerance in faba bean [185]. Similarly, transgenic lines of chickpea with the AP2-type TFs, CAP2, improve SS tolerance [184]. In alfalfa, Bai et al. [186] observed that GsCBRLK enhanced SS tolerance by improving chlorophyll content and by lowering malondialdehyde (MDA) content and membrane leakage. Likewise, overexpression of GsCBRLK in soybean improves salinity tolerance by enhancing photosynthesis and scavenging ROS [187]. In another study, overexpression of TaNHX2 improved salinity resistance in transgenic soybean plants [188]. Bao et al. [189] also 
reported enhanced tolerance to salt in transgenic alfalfa due to the overexpression of Arabidopsis $\mathrm{H}^{+}$Pase. The expression of genes induced by SS and its regulation comprise a range of molecular mechanisms that are controlled via several TFs in various plant species. These TFs regulate and initiate genes transcription or gene products specified for salinity tolerance. Therefore, the role of transcriptomics approaches in gene regulation, its expression, and identification of genes involved in salinity tolerance has been useful in recent times. In legumes, various TFs have been identified to impart salinity tolerance, such as GmNACs, GmAP2/ERFs, and GmTDF-5 in soybean, MtNAC969 in barrel clover, GsZFP1 and AtAvp1 ( $\mathrm{H}^{+}$-PPases) in alfalfa $[190,191]$. Tripathi et al. [191] reported a number of families of TFs, e.g., AP2/ERF, WRKY, bHLH, and NAC, which have been linked with SS tolerance in groundnut. Similarly, transgenic lines of chickpea with the putative NAC-type TF, CarNAC4, improve salinity tolerance by decreasing MDA concentration [192]. Sarkar et al. [193] reported TF (DREB1A) in groundnut plants confer SS tolerance at the seedling stage. Similarly, the DREB1A gene played a similar function in alleviating salinity stress tolerance in lentil [194].

Mutation breeding has been extensively used to develop salt-tolerant legumes but it is a laborious approach as several plant generations are required to identify the mutation of the targeted genome [195]. The WGS approach has made it a faster and easy method as mutations can be identified and mapped simultaneously [196]. The identification of genes induced by SS using WGS and SNP technologies may be useful to develop stress-tolerant genotypes and understanding of molecular mechanisms of salinity tolerance [197]. The NGS can also be used to study differential gene expression in saline conditions enabling the identification of target-induced mutations in fewer generations [198-200].

Table 2. Transgenic legumes for better salt tolerance.

\begin{tabular}{|c|c|c|c|c|}
\hline $\begin{array}{l}\text { Transgenic } \\
\text { Crop }\end{array}$ & $\begin{array}{c}\text { Gene } \\
\text { Transferred }\end{array}$ & Source & Function & Reference \\
\hline \multirow{3}{*}{ Soybean } & P5CS & Solanum torvum Sw. & Synthesis and accumulation of proline & [200] \\
\hline & TaNHX2 & T. aestivum $\mathrm{L}$. & Sodium vacuolar sequestration & [188] \\
\hline & WRKY11 & Medicago sativa $\mathrm{L}$. & Improves salt tolerance & [201] \\
\hline \multirow{2}{*}{ Pea } & $\mathrm{Na}^{+} / \mathrm{H}^{+}$ & Arabidopsis thaliana $\mathrm{L}$. & Sodium vacuolar sequestration & [202] \\
\hline & P5CS & Arabidopsis thaliana $\mathrm{L}$. & Synthesis and accumulation of proline & [203] \\
\hline Chickpea & P5CS & Vigna aconitifolia L. & Synthesis and accumulation of proline & [204] \\
\hline Faba bean & PR10a & Solanum tuberosum $\mathrm{L}$. & Synthesis and accumulation of osmolytes & [185] \\
\hline Mashbean & gly I & Brassica juncea $\mathrm{L}$. & Increase in antioxidant ability & [205] \\
\hline \multirow{2}{*}{ Pigeon pea } & VaP5CSF129A & Vigna aconitifolia L. & Synthesis and accumulation of proline & [206] \\
\hline & VaP5CSF129A & Vigna aconitifolia L. & Synthesis and accumulation of osmolytes & [207] \\
\hline Lentil & DREB1A & Arabidopsis thaliana $\mathrm{L}$. & Synthesis and accumulation of osmolytes & [194] \\
\hline \multirow{3}{*}{ Peanut } & AtNHXI & Arabidopsis thaliana $\mathrm{L}$. & Sodium vacuolar sequestration & [208] \\
\hline & AtDREB1A & Arabidopsis thaliana $\mathrm{L}$. & Improves salt tolerance & [193] \\
\hline & AtHDG11 & Arabidopsis thaliana $\mathrm{L}$. & Improves salt tolerance & [209] \\
\hline \multirow{8}{*}{ Alfalfa } & SsNHX1 & Suaeda salsa & Regulate plant $\mathrm{Na}^{+} / \mathrm{H}^{+}$antiporters & [210] \\
\hline & CsALDH12A1 & Cleistogenes songorica $\mathrm{L}$. & Improves salt tolerance & [211] \\
\hline & GmDREB1 & Glycine $\max \mathrm{L}$. & Conferred salt tolerance & [212] \\
\hline & $\mathrm{IbOr}$ & Ipomoea batatas L. & Increased tolerance to multiple abiotic stresses & [213] \\
\hline & GsCBRLK & Glycine soja $\mathrm{L}$. & Improves salt tolerance & [186] \\
\hline & TaNHX2 & Triticum aestivum $\mathrm{L}$. & Regulate plant $\mathrm{Na}^{+} / \mathrm{H}^{+}$antiporters & [214] \\
\hline & $\begin{array}{l}\text { ScNHX1 and } \\
\text { ScVP }\end{array}$ & Suaeda corniculata & $\begin{array}{l}\text { Vacuolar membrane } \mathrm{H}^{+} \text {-pyrophosphatases and } \\
\mathrm{H}^{+} \text {-ATPases }\end{array}$ & [215] \\
\hline & GsZFP1 & Glycine soja $\mathrm{L}$. & Improves salinity tolerance & [216] \\
\hline
\end{tabular}




\subsection{CRISPR-Cas9: Master Player for Genome Editing (GE)}

Genome editing (GE), as the name implies, is the targeted mutagenesis of the genome. Current tools allow us to introduce specific modifications at target sites in the genome. Due to comprehensive genomic research, plenty of information is available about salinity tolerance in plants. The role of small RNAs, proteins, and different genes under stress environments is well-defined. The genetic transformation of plants for enhancing salinity tolerance and increasing yield is successful up to some extent [217]. This has been done by adopting biotechnological approaches, such as screening, cloning, overexpression, and crossing, which are time consuming and laborious. To tackle these issues, novel GE tools were introduced. Targeted mutation, precise sequence modification, deletion, or insertion can be achieved by using these tools. At present, CRISPR-Cas9, Transcriptional activator-like effector nuclease (TALENs), and zinc finger nuclease (ZFNs) are available for GE [218]. Out of these three tools, CRISPR-Cas9 can manipulate any genome sequence to study its function [219] (Figure 4). These tools' applications will lead to the development of non-genetically modified crop plants with the wanted trait that can contribute to improved crop productivity under stress environments [220]. In recent years, GE by CRISPR/Cas9 has been observed in many crops, including rice [221], wheat [222-224], maize [225,226], barley [227,228], rapeseed [226], potato [228], sweet orange [229], soybean [230-232], poplar [232], and petunia [233]. Abdelrahman and co-workers reviewed the targeted mutagenesis in crop plants by CRISPR/Cas9. They report CRISPR/Cas9-mediated GE in many crops for yield improvements of crop plants grown under unfavorable conditions [234]. Mushtaq et al. [235] reviewed recent applications of the CRISPR/Cas9-mediated GE as a means to develop crop plants with increased tolerance to the abiotic stresses they encounter when grown under unfavorable conditions. CRISPRCas9 is a powerful tool in engineering for salt tolerance in legumes but fewer investigations have been done previously in GE for SS tolerance in legumes. The use of targeted GE tools, especially CRISPR/Cas9, has great potential to develop high-yielding legumes under saline conditions.

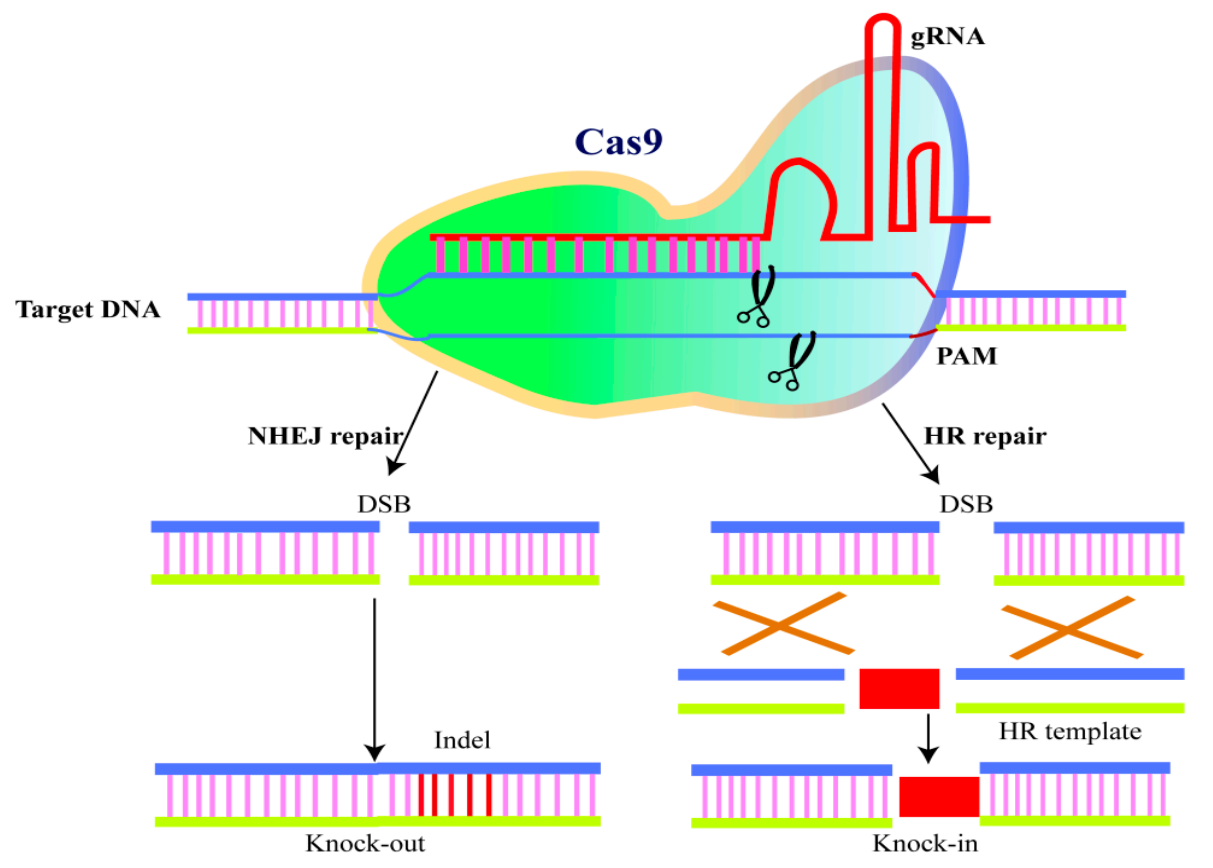

Figure 4. Schematic representation of Cas9/gRNA genome editing. CRISPR/Cas9 system consists of sgRNA and Cas9 nuclease. The sgRNA directs the sequence-specific Cas9 nuclease to start double-strand DNA breaks in the target DNA. The cell's DNA repair machinery, comprising HR and NHEJ pathways, repairs the strand breaks, creating a short deletion/insertion (gene knockout), new sequence insertion and/or sequence modification. sgRNA, single guide RNA; HR, homologous recombination; NHEJ, non-homologous end joining (adopted and modified from [236]). 


\section{Conclusions and Future Research Perspectives}

Crop production is adversely affected by SS. It is quite evident that SS significantly affects legume yield and currently has become a prime concern for crop production. Legumes undergo various adaptations, for instance, osmotic adjustment and osmoregulation, activation of antioxidant defense systems, hormonal regulation, and mechanisms, such as lethal ion elimination, to survive under SS. There is an immense need to develop new legume varieties with stable and higher yield across unfavorable environments. Availability of legume genomes will aid in the identification of genes that could be deployed for use in transgenic or breeding approaches to develop salt-tolerant legumes. Recent investigations identified molecular markers, QTL, and genes associated with stress tolerance which can help to improve growth and yield under saline conditions. This review not only provides knowledge and understanding about the effect of salinity stress on legumes but also gives us knowledge about the mechanisms and management strategies to improve legume yield. Although the investigation of SS responses has progressed well in cereals and other plants, it still has a long way to go in legume crops. Identification of SS-induced genes in several legume crops, in-depth study of downstream and upstream elements, and comprehensive study of gene expression at different developmental stages with advanced tools will help in elucidating and understanding this trait. Bioinformatics has emerged as a useful tool to make the omics data available to researchers through the establishment of public databases. Hence, there is a need to create databases comprising information on metabolomics, ionomics, and phenomics, particularly in grain legumes. Recently, speed breeding (SB) technique gained attention of researchers because it enables growing up to six plant generations in a single year. The integration of SB with other advanced crop breeding approaches, including GE, high-throughput genotyping, and genomic selection, accelerating the rate of crop improvement under unfavorable conditions [237]. In the future, integration of several approaches, such as genomic, transcriptomic, proteomic, metabolomics, and agronomic strategists, as well as advanced GE tools (CRISPR- Cas9) is warranted to develop legume varieties with high salt tolerance under saline conditions (Figure 5).

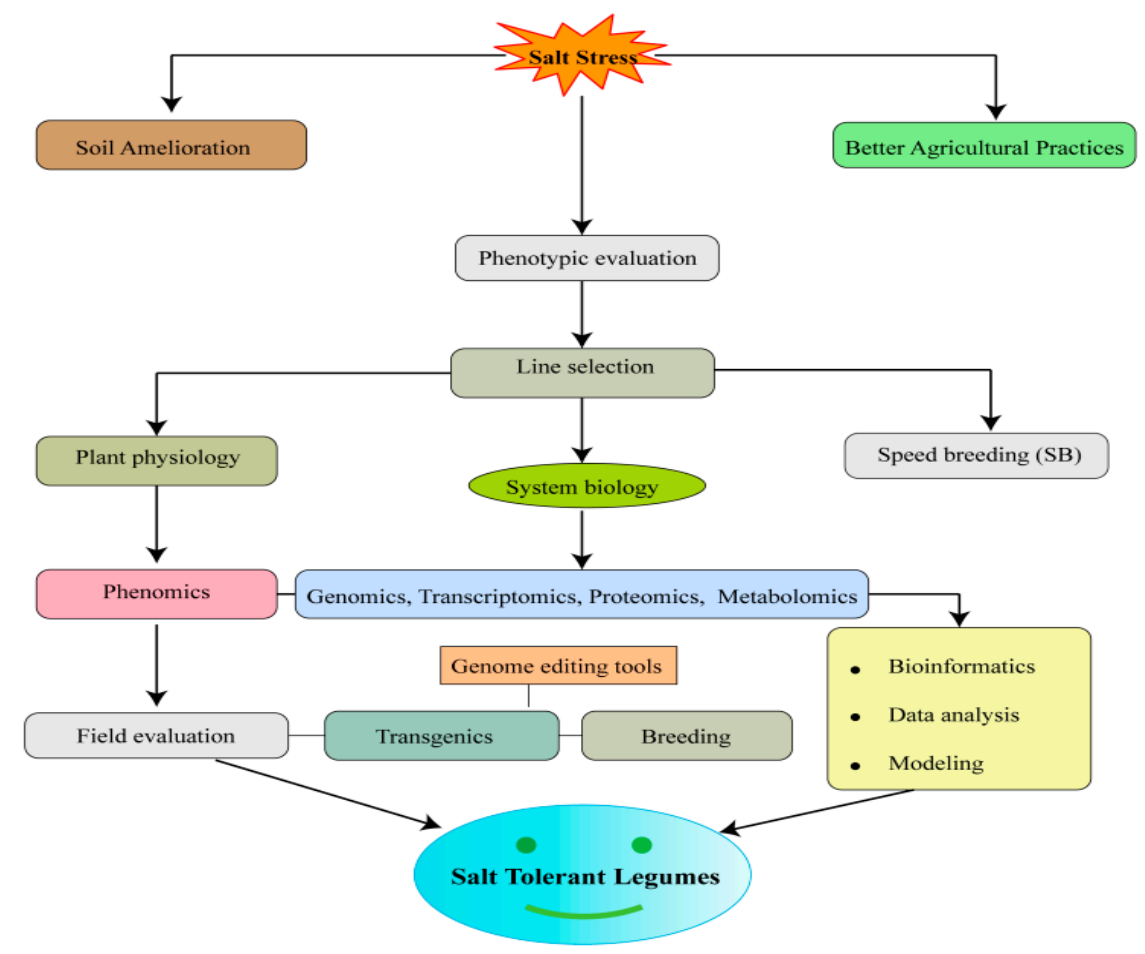

Figure 5. Schematic representation of approaches for developing of salt tolerant legumes. The integration of "omics" approaches along with advance genome editing (GE) tools and agronomic approaches can improve salt tolerance in legumes. 
Funding: This work was supported by the National Key Research and Development Program of China (2016YFD0100201), the Program of National Natural Science Foundation of China (NSFC, 31771819), the China Postdoctoral Science Foundation (2017M621990), the Natural Science for Key Project of Anhui Education Committee (KJ2016A843), and the Postdoctoral Science Foundation of Anhui Province, China (2017B187).

Conflicts of Interest: The authors declare no conflicts of interest.

\section{Abbreviations}

$\begin{array}{ll}\text { GA } & \text { Gibberellin } \\ \text { ABA } & \text { Abscisic acid } \\ \text { SOS } & \text { Salt overly sensitive } \\ \text { GB } & \text { Glycine betaine } \\ \text { ROS } & \text { Reactive oxygen species } \\ \text { GR } & \text { Glutathione reductase } \\ \text { GPX } & \text { Glutathione peroxidases } \\ \text { APX } & \text { Ascorbate peroxidase } \\ \text { SOD } & \text { Superoxide dismutase } \\ \text { GST } & \text { Glutathione S-transferases } \\ \text { MDHAR } & \text { Monodehydroascorbate reductase } \\ \text { CAT } & \text { Catalase } \\ \text { PGPR } & \text { Plant growth promoting rhizobacteria } \\ \text { WGS } & \text { Whole genome sequencing } \\ \text { SNP } & \text { Single-nucleotide polymorphism } \\ \text { SSRs } & \text { Simple sequence repeats } \\ \text { NGS } & \text { Next-generation sequencing } \\ \text { MDA } & \text { Malondialdehyde } \\ \text { GE } & \text { Genome editing } \\ \text { TALENs } & \text { Transcriptional activator-like effector nuclease } \\ \text { ZFNs } & \text { Zinc finger nuclease }\end{array}$

\section{References}

1. Kromdijk, J.; Long, S.P. One crop breeding cycle from starvation? How engineering crop photosynthesis for rising $\mathrm{CO}_{2}$ and temperature could be one important route to alleviation. Proc. R. Soc. B Biol. Sci. 2016, 283. [CrossRef]

2. Pareek, A.; Sopory, S.K.; Bohnert, H.J. Govindjee Abiotic stress adaptation in plants: Physiological, molecular and genomic foundation. Abiotic Stress Adapt. Plants Physiol. Mol. Genomic Found. 2010, 99, 1-526. [CrossRef]

3. Kaashyap, M.; Ford, R.; Bohra, A.; Kuvalekar, A.; Mantri, N. Improving salt tolerance of chickpea using modern genomics tools and molecular breeding. Curr. Genom. 2017, 18, 557-567. [CrossRef]

4. Nadeem, M.; Li, J.; Wang, M.; Shah, L.; Lu, S.; Wang, X.; Ma, C. Unraveling field crops sensitivity to heat stress: Mechanisms, approaches, and future prospects. Agronomy 2018, 8, 128. [CrossRef]

5. El-nasharty, A.B.; El-nwehy, S.S.; Rezk, A.I.; El-Motaleb Aly Abou El-Nour, E.-Z.A. Role of kinetin in improving salt tolerance of two wheat cultivars. Biosci. Res. 2017, 2, 193-200.

6. Food and Agriculture Organization of the United Nations. Status World's Soil Resources; FAO: Rome, Italy, 2015; 650p, ISBN 978-92-5-109004-6.

7. Flowers, T.J.; Flowers, S.A. Why does salinity pose such a difficult problem for plant breeders? Agric. Water Manag. 2005, 78, 15-24. [CrossRef]

8. Qureshi, M.I.; Muneer, S.; Bashir, H.; Ahmad, J.; Iqbal, M. Nodule physiology and proteomics of stressed legumes. Adv. Bot. Res. 2010, 56, 1-48.

9. Mishra, S.; Panda, S.K.; Sahoo, L. Transgenic asiatic grain legumes for salt tolerance and functional genomics. Rev. Agric. Sci. 2014, 2, 21-36. [CrossRef]

10. Flexas, J.; Bota, J.; Loreto, F.; Cornic, G.; Sharkey, T.D. Diffusive and metabolic limitations to photosynthesis under drought and salinity in C3 plants. Plant Biol. 2004, 6, 269-279. [CrossRef] 
11. Murillo-Amador, B.; Yamada, S.; Yamaguchi, T.; Rueda-Puente, E.; Ávila-Serrano, N.; García-Hernández, J.L.; López-Aguilar, R.; Troyo-Diéguez, E.; Nieto-Garibay, A. Influence of calcium silicate on growth, physiological parameters and mineral nutrition in two legume species under salt stress. J. Agron. Crop Sci. 2007, 193, 413-421. [CrossRef]

12. He, Y.; Fu, J.; Yu, C.; Wang, X.; Jiang, Q.; Hong, J.; Lu, K.; Xue, G.; Yan, C.; James, A.; et al. Increasing cyclic electron flow is related to $\mathrm{Na}^{+}$sequestration into vacuoles for salt tolerance in soybean. J. Exp. Bot. 2015, 66, 6877-6889. [CrossRef] [PubMed]

13. Patil, G.; Do, T.; Vuong, T.D.; Valliyodan, B.; Lee, J.D.; Chaudhary, J.; Shannon, J.G.; Nguyen, H.T. Genomic-assisted haplotype analysis and the development of high-throughput SNP markers for salinity tolerance in soybean. Sci. Rep. 2016, 6, 1-13. [CrossRef] [PubMed]

14. López-Aguilar, R.; Orduño-Cruz, A.; Lucero-Arce, A.; Murillo-Amador, B.; Troyo-Diéguez, E. Response to salinity of three grain legumes for potential cultivation in arid areas. Soil Sci. Plant Nutr. 2003, 49, 329-336. [CrossRef]

15. Manchanda, G.; Garg, N. Salinity and its effects on the functional biology of legumes. Acta Physiol. Plant. 2008, 30, 595-618. [CrossRef]

16. Sehrawat, N.; Bhat, K.V.; Sairam, R.K.; Jaiwal, P.K. Identification of salt resistant wild relatives of mungbean (Vigna radiata L. Wilczek). Asian J. Plant Sci. Res. 2013, 3, 41-49.

17. Khan, H.A.; Siddique, K.H.M.; Colmer, T.D. Vegetative and reproductive growth of salt-stressed chickpea are carbon-limited: Sucrose infusion at the reproductive stage improves salt tolerance. J. Exp. Bot. 2017, 68, 2001-2011. [CrossRef]

18. Flowers, T.J.; Gaur, P.M.; Gowda, C.L.L.; Krishnamurthy, L.; Samineni, S.; Siddique, K.H.M.; Turner, N.C.; Vadez, V.; Varshney, R.K.; Colmer, T.D. Salt sensitivity in chickpea. Plant Cell Environ. 2010, 33, 490-509. [CrossRef]

19. Parihar, P.; Singh, S.; Singh, R.; Singh, V.P.; Prasad, S.M. Effect of salinity stress on plants and its tolerance strategies: A review. Environ. Sci. Pollut. Res. 2015, 22, 4056-4075. [CrossRef] [PubMed]

20. Van Hoorn, J.W.; Katerji, N.; Hamdy, A.; Mastrorilli, M. Effect of salinity on yield and nitrogen uptake of four grain legumes and on biological nitrogen contribution from the soil. Agric. Water Manag. 2001, 51, 87-98. [CrossRef]

21. Yadav, H.D.; Yadav, O.P.; Dhankar, O.P.; Oswal, M.C. Effect of chloride salintiy and gernmination, growth and mineral composition of chickpea. Ann. Arid Zone 1989, 28, 63-67.

22. El Sayed, H.E.S. Influence of $\mathrm{NaCl}$ and $\mathrm{Na}_{2} \mathrm{SO}_{4}$ treatments on growth development of broad bean (Vicia faba L.) plant. J. Life Sci. 2011, 5, 513-523.

23. Munns, R.; Tester, M. Mechanisms of salinity tolerance. Annu. Rev. Plant Biol. 2008, 59, 651-681. [CrossRef] [PubMed]

24. Munns, R. Genes and salt tolerance: Bringing them togethe. New Phytol. 2005, 167, 645-663. [CrossRef] [PubMed]

25. Farooq, M.; Hussain, M.; Wakeel, A.; Siddique, K.H.M. Salt stress in maize: Effects, resistance mechanisms, and management. A review. Agron. Sustain. Dev. 2015, 35, 461-481. [CrossRef]

26. Shu, K.; Qi, Y.; Chen, F.; Meng, Y.; Luo, X.; Shuai, H.; Zhou, W.; Ding, J.; Du, J.; Liu, J.; et al. Salt stress represses soybean seed germination by negatively regulating GA biosynthesis while positively mediating ABA biosynthesis. Front. Plant Sci. 2017, 8, 1-12. [CrossRef] [PubMed]

27. Kumar, A. Germination behaviour of soybean varieties under different salinity stress. Int. J. Appl. Agric. Res. 2017, 12, 69-76.

28. Ma, Q.; Kang, J.; Long, R.; Zhang, T.; Xiong, J.; Zhang, K.; Wang, T.; Yang, Q.; Sun, Y. Comparative proteomic analysis of alfalfa revealed new salt and drought stress-related factors involved in seed germination. Mol. Biol. Rep. 2017, 44, 261-272. [CrossRef]

29. Haileselasie, T.H.; Teferii, G. The effect of salinity stress on germination of chickpea (Cicer arietinum L.) Land Race of Tigray. Curr. Res. J. Biol. Sci. 2012, 4, 578-583.

30. Bayuelo-Jiménez, J.S.; Craig, R.; Lynch, J.P. Salinity tolerance of Phaseolus species during germination and early seedling growth. Crop Sci. 2002, 42, 1584-1594. [CrossRef]

31. Al-Mutawa, M.M. Effect of salinity on germination and seedling growth of chickpea (Cicer arietinum) genotypes. Int. J. Agric. Biol. 2003, 5, 226-229. [CrossRef] 
32. Sehrawat, N.; Yadav, M.; Bhat, K.; Sairam, R.; Jaiwal, P. Effect of salinity stress on mungbean [Vigna radiata (L.) Wilczek] during consecutive summer and spring seasons. J. Agric. Sci. Belgrade 2015, 60, 23-32. [CrossRef]

33. Luo, G.Z.; Wang, Y.J.; Xie, Z.M.; Gai, J.Y.; Zhang, J.S.; Chen, S.Y. The putative ser/thr protein kinase gene CmAAPK from soybean is regulated by abiotic stress. J. Integr. Plant Biol. 2006, 48, 327-333. [CrossRef]

34. Bandeoğlu, E.; Eyidoğan, F.; Yücel, M.; Öktem, H.A. Antioxidant responses of shoots and roots of lentil to NaCl-salinity stress. Plant Growth Regul. 2004, 42, 69-77. [CrossRef]

35. Pitann, B.; Kranz, T.; Zörb, C.; Walter, A.; Schurr, U.; Mühling, K.H. Apoplastic pH and growth in expanding leaves of Vicia faba under salinity. Environ. Exp. Bot. 2011, 74, 31-36. [CrossRef]

36. Garg, N.; Bhandari, P. Silicon nutrition and mycorrhizal inoculations improve growth, nutrient status, $\mathrm{K}^{+} / \mathrm{Na}^{+}$ratio and yield of Cicer arietinum L. genotypes under salinity stress. Plant Growth Regul. 2016, 78, 371-387. [CrossRef]

37. Garg, N.; Manchanda, G. Role of arbuscular mycorrhizae in the alleviation of ionic, osmotic and oxidative stresses induced by salinity in Cajanus cajan (L.) Millsp. (pigeonpea). J. Agron. Crop Sci. 2009, 195, 110-123. [CrossRef]

38. Do, T.D.; Vuong, T.D.; Dunn, D.; Smothers, S.; Patil, G.; Yungbluth, D.C.; Chen, P.; Scaboo, A.; Xu, D.; Carter, T.E.; et al. Mapping and confirmation of loci for salt tolerance in a novel soybean germplasm, Fiskeby III. Theor. Appl. Genet. 2018, 131, 513-524. [CrossRef]

39. Ning, L.; Kan, G.; Shao, H.; Yu, D. Physiological and transcriptional responses to salt stress in salt-tolerant and salt-sensitive soybean (Glycine max [L.] Merr.) seedlings. L. Degrad. Dev. 2018, 29, 2707-2719. [CrossRef]

40. Eyidogan, F.; Öz, M.T. Effect of salinity on antioxidant responses of chickpea seedlings. Acta Physiol. Plant. 2007, 29, 485-493. [CrossRef]

41. Khan, H.A.; Siddique, K.H.M.; Munir, R.; Colmer, T.D. Salt sensitivity in chickpea: Growth, photosynthesis, seed yield components and tissue ion regulation in contrasting genotypes. J. Plant Physiol. 2015, 182, 1-12. [CrossRef] [PubMed]

42. Lu, Y.; Lei, J.Q.; Zeng, F.J.; Zhang, B.; Liu, G.J.; Liu, B.; Li, X.Y. Effect of NaCl-induced changes in growth, photosynthetic characteristics, water status and enzymatic antioxidant system of Calligonum caput-medusae seedlings. Photosynthetica 2017, 55, 96-106. [CrossRef]

43. Shanko, D.; Jateni, G.; Debela, A. Effects of salinity on chickpea (Cicer arietinum L.) landraces during germination stage. Biochem. Mol. Biol. J. 2017, 03, 214-219. [CrossRef]

44. Kaya, M.D.; Ipek, A.; Öztürk, A. Effects of different soil salinity levels on germination and seedling growth of safflower (Carthamus tinctorius L.). Turk. J. Agric. For. 2003, 27, 221-227. [CrossRef]

45. Talei, D.; Kadir, M.A.; Yusop, M.K.; Abdullah, M.P.; Valdiani, A. Salinity effects on macro and micronutrients uptake in medicinal plant King of Bitters (Andrographis paniculata Nees.). Plant Omics 2012, 5, 271-278. [CrossRef]

46. Greenway, H.; Munns, R. Mechanisms of salt tolerance in nonhalophytes. Annu. Rev. Plant Physiol. 1980, 31, 149-190. [CrossRef]

47. Torabian, S.; Farhangi-Abriz, S.; Rathjen, J. Biochar and lignite affect $\mathrm{H}^{+}$-ATPase and $\mathrm{H}^{+}$-PPase activities in root tonoplast and nutrient contents of mungbean under salt stress. Plant Physiol. Biochem. 2018, 129, 141-149. [CrossRef] [PubMed]

48. Nandwal, A.S.; Godara, M.; Kamboj, D.V.; Kundu, B.S.; Mann, A.; Kumar, B.; Sharma, S.K. Nodule functioning in trifoliate and pentafoliate mungbean genotypes as influenced by salinity. Biol. Plant. 2000, 43, 459-462. [CrossRef]

49. Gholipoor, M.; Ghasemi-Golezani, K.; Khooie, F.R.; Moghaddam, M. Effects of salinity on initial seedling growth of chickpea (Cicer Arietinum L.). Acta Agron. Hungarica 2001, 48, 337-343. [CrossRef]

50. Essa, T.A. Effect of salinity stress on growth and nutrient composition of three soybean (Glycine max L. Merrill) Cultivars. J. Agron. Crop Sci. 2002, 93, 86-93. [CrossRef]

51. Rabie, G.H.; Almadini, A.M. Role of bioinoculants in development of salt-tolerance of Vicia faba plants under salinity stress. Afr. J. Biotechnol. 2005, 4, 210-222. [CrossRef]

52. Cordovilla, M.P.; Ocaña, A.; Ligero, F.; Lluch, C. Salinity effects on growth analysis and nutrient composition in four grain ulgumes-rhizobium symbiosis. J. Plant Nutr. 1995, 18, 1595-1609. [CrossRef]

53. Sarath, G.; Wagner, F.W. Bacteroids Are Stable during Dark-Induced Senescence of Soybean Root Nodules. Plant Physiol. 1986, 1986. 82, 346-350. [CrossRef] 
54. Khan, M.S.A.; Karim, M.A.; Haque, M.M.; Islam, M.M.; Karim, A.J.M.S.; Mian, M.A.K. Influence of salt and water stress on growth and yield of soybean genotypes. Trop. Agric. Sci. 2016, 39, 167-180.

55. Ghassemi-Golezani, K.; Taifeh-Noori, M.; Oustan, S. Oil and protein accumulation in soybean grains under salinity stress. Not. Sci. Biologicae 2010, 2, 64-67. [CrossRef]

56. Kumar, S.; Promila, K. Effects of chloride and sulfate types of salinization and desalinization on nodulation and nitrogenfixation in chickpea. Indian J. Plant Physiol. 1983, 26, 396-401.

57. Vadez, V.; Krishnamurthy, L.; Serraj, R.; Gaur, P.M.; Upadhyaya, H.D.; Hoisington, D.A.; Varshney, R.K.; Turner, N.C.; Siddique, K.H.M. Large variation in salinity tolerance in chickpea is explained by differences in sensitivity at the reproductive stage. Field Crop. Res. 2007, 104, 123-129. [CrossRef]

58. Ahmed, S. Effect of soil salinity on the yield and yield components of mungbean. Pak. J. Bot. 2009, 41, 263-268.

59. Farooq, M.; Gogoi, N.; Hussain, M.; Barthakur, S.; Paul, S.; Bharadwaj, N.; Migdadi, H.M.; Alghamdi, S.S.; Siddique, K.H.M. Effects, tolerance mechanisms and management of salt stress in grain legumes. Plant Physiol. Biochem. 2017, 118, 199-217. [CrossRef]

60. Qados, A.M.S.A. Effect of salt stress on plant growth and metabolism of bean plant Vicia faba (L.). J. Saudi Soc. Agric. Sci. 2011, 10, 7-15. [CrossRef]

61. Qados, A.M.S.A. Effect of arginine on growth, nutrient composition, yield and nutritional value of mungbean plants grown under salinity stress. Nature. 2010, 8, 30-42.

62. Katerji, N.; Hamdy, A.; Mastrorilli, M. Salt tolerance classification of crops according to soil salinity and to water stress day index. Agric. Water Manag. 2000, 43, 99-109. [CrossRef]

63. Hasegawa, P.M.; Bressan, R.A. Plant cellular and molecular responses to high salinity. Annu. Rev. Plant Physiol. Plant Mol. Biol. 2000, 51, 463-499. [CrossRef] [PubMed]

64. Li, W.Y.F.; Wong, F.L.; Tsai, S.N.; Phang, T.H.; Shao, G.; Lam, H.M. Tonoplast-located GmCLC1 and GmNHX1 from soybean enhance $\mathrm{NaCl}$ tolerance in transgenic bright yellow (BY)-2 cells. Plant Cell Environ. 2006, 29, 1122-1137. [CrossRef]

65. Subbarao, G.V.; Johansen, C.; Jana, M.K.; Kumar Rao, J.V.D.K. Effects of the sodium/calcium ratio in modifying salinity response of pigeonpea (Cajanus cajan). J. Plant Physiol. 1990, 136, 439-443. [CrossRef]

66. Waheed, A.; Hafiz, I.A.; Qadir, G.; Murtaza, G.; Mahmood, T.; Ashraf, M. Effect of salinity on germination, growth, yield, ionic balance and solute composition of Pigeon pea (Cajanus cajan (L.) Millsp). Pak. J. Bot. 2006, 38, 1103-1117. [CrossRef]

67. Turner, N.C.; Colmer, T.D.; Quealy, J.; Pushpavalli, R.; Krishnamurthy, L.; Kaur, J.; Singh, G.; Siddique, K.H.M.; Vadez, V. Salinity tolerance and ion accumulation in chickpea (Cicer arietinum L.) subjected to salt stress. Plant Soil 2013, 365, 347-361. [CrossRef]

68. Phang, T.H.; Shao, G.; Lam, H.M. Salt tolerance in soybean. J. Integr. Plant Biol. 2008, 50, 1196-1212. [CrossRef] [PubMed]

69. Lacan, D.; Durand, M. Na $-\mathrm{K}^{+}$exchange at the xylem/symplast boundary (Its significance in the salt sensitivity of soybean). Plant Physiol. 1996, 110, 705-711. [CrossRef]

70. Yu, B.J.; Lam, H.M.; Shao, G.H.; Liu, Y.L. Effects of salinity on activities of $\mathrm{H}^{+}$-ATPase, $\mathrm{H}^{+}$-PPase and membrane lipid composition in plasma membrane and tonoplast vesicles isolated from soybean (Glycine max L.) seedlings. J. Environ. Sci. 2005, 17, 259-262.

71. Sanders, D. Plant biology: The salty tale of Arabidopsis. Curr. Biol. 2000, 10, 486-488. [CrossRef]

72. Shi, H.; Ishitani, M.; Kim, C.; Zhu, J.K. The Arabidopsis thaliana salt tolerance gene SOS1 encodes a putative $\mathrm{Na}^{+} / \mathrm{H}^{+}$antiporter. Proc. Natl. Acad. Sci. USA 2000, 97, 6896-6901. [CrossRef]

73. Liu, J. The Arabidopsis thaliana SOS2 gene encodes a protein kinase that is required for salt tolerance. Proc. Natl. Acad. Sci. USA 2000, 97, 3730-3734. [CrossRef] [PubMed]

74. Ishitani, M. SOS3 function in plant salt tolerance requires N-myristoylation and calcium binding. Plant Cell Online 2000, 12, 1667-1678. [CrossRef]

75. Garg, N.; Noor, Z. Genotypic differences in plant growth, osmotic and antioxidative defence of Cajanus cajan (L.) Millsp. modulated by salt stress. Arch. Agron. Soil Sci. 2009, 55, 3-33. [CrossRef]

76. Panda, M.D.K. Salt stress induced changes in growth and enzyme activities in germinating Phaseolus mungo seeds. Biol. Plant. 2001, 44, 587-589. [CrossRef]

77. Sumithra, K.; Jutur, P.P.; Carmel, B.D.; Reddy, A.R. Salinity-induced changes in two cultivars of Vigna radiata: Responses of antioxidative and proline metabolism. Plant Growth Regul. 2006, 50, 11-22. [CrossRef] 
78. Qurashi, A.W.; Sabri, A.N. Osmolyte accumulation in moderately halophilic bacteria improves salt tolerance of chickpea. Pak. J. Bot. 2013, 45, 1011-1016.

79. El Sabagh, A.; Sorour, S.; Omar, A.E.; Ragab, A.; Islam, M.S.; Ueda, A.; Saneoka, H. Alleviation of adverse effects of salt stress on soybean (Glycine max. L.) by using osmoprotectants and organic nutrients. Int. J. Innov. Res. Sci. Eng. 2015, 9, 921-925.

80. Enrique Olmos, E.H. Mechanisms of salt tolerance in a cell line of Pisum sativum. Plant Sci. 1996, 120, 37-45. [CrossRef]

81. Hernandez, J.A.; Campillo, A.; Jimenez, A.; Alarcon, J.J.; Sevilla, F. Response of antioxidant systems and leaf water relations to $\mathrm{NaCl}$ stress in pea plants. New Phytol. 1999, 141, 241-251. [CrossRef]

82. Kukreja, S.; Nandwal, A.S.; Kumar, N.; Sharma, S.K.; Sharma, S.K.; Unvi, V.; Sharma, P.K. Plant water status, $\mathrm{H}_{2} \mathrm{O}_{2}$ scavenging enzymes, ethylene evolution and membrane integrity of Cicer arietinum roots as affected by salinity. Biol. Plant. 2005, 49, 305-308. [CrossRef]

83. Hernández, J.A.; Jiménez, A.; Mullineaux, P.; Sevilla, F. Tolerance of pea (Pisum sativum L.) to long-term salt stress is associated with induction of antioxidant defences. Plant Cell Environ. 2000, 23, 853-862. [CrossRef]

84. Yasar, F.; Ellialtioglu, S.; Yildiz, K. Effect of salt stress on antioxidant defense systems, lipid peroxidation, and chlorophyll content in green bean. Russ. J. Plant Physiol. 2008, 55, 782-786. [CrossRef]

85. Zhu, J.K. Abiotic stress signaling and responses in plants. Cell 2016, 167, 313-324. [CrossRef] [PubMed]

86. Vishwakarma, K.; Upadhyay, N.; Kumar, N.; Yadav, G.; Singh, J.; Mishra, R.K.; Kumar, V.; Verma, R.; Upadhyay, R.G.; Pandey, M.; et al. Abscisic acid signaling and abiotic stress tolerance in plants: A review on current knowledge and future prospects. Front. Plant Sci. 2017, 08, 1-12. [CrossRef]

87. Singh, N.K.; Larosa, P.C.; Handa, A.K.; Hasegawa, P.M.; Bressan, R.A. Hormonal regulation of protein synthesis associated with salt tolerance in plant cells. Proc. Natl. Acad. Sci. USA 1987, 84, 739-743. [CrossRef]

88. Wolf, O.; Jeschke, W.D. Long distance transport of abscisic acid in NaCl-treated intact plants of Lupinus albus. J. Exp. Bot. 1990, 5, 593-600. [CrossRef]

89. Grattan, S.R.; Grieve, C.M. Salinity-mineral nutrient relations in horticultural crops. Sci. Hortic. (Amst.) 1998, 78, 127-157. [CrossRef]

90. Hu, Y.; Schmidhalter, U. Drought and salinity: A comparison of their effects on mineral nutrition of plants. J. Plant Nutr. Soil Sci. 2005, 168, 541-549. [CrossRef]

91. Pandey, S.K.; Pathak, L.P.; Pathak, R.K. Effect of some nutrients in rice plant under sodic soils. Int. J. Tech. Res. Appl. 2013, 1, 9-18.

92. Ezeaku, P.; Ene, J.; Shehu, J. Application of different reclamation methods on salt affected soils for crop production. Am. J. Exp. Agric. 2015, 9, 1-11. [CrossRef]

93. Hussain, Z.; Khattak, R.A.; Irshad, M.; Mahmood, Q.; An, P. Effect of saline irrigation water on the leachability of salts, growth and chemical composition of wheat (Triticum aestivum L.) in saline-sodic soil supplemented with phosphorus and potassium. J. Soil Sci. Plant Nutr. 2016, 16, 604-620. [CrossRef]

94. Ma, T.; Zeng, W.; Li, Q.; Wu, J.; Huang, J. Effects of water, salt and nitrogen stress on sunflower (Helianthus annuus L.) at different growth stages. J. Soil Sci. Plant Nutr. 2016, 16, 1024-1037. [CrossRef]

95. Hussain, N.; Hassan, G.; Arshadullah, M.; Mujeeb, F. Evaluation of amendments for the improvement of physical properties of sodic soil. Int. J. Agric. Biol. 2001, 3, 319-322.

96. Manzoor, A.; Khattak, R.A.; Dost, M. Humic acid and micronutrient effects on wheat yield and nutrients uptake in salt affected soils. Int. J. Agric. Biol. 2014, 16, 991-995.

97. Matuszak-Slamani, R.; Bejger, R.; Cieśla, J.; Bieganowski, A.; Koczańska, M.; Gawlik, A.; Kulpa, D.; Sienkiewicz, M.; Włodarczyk, M.; Gołębiowska, D. Influence of humic acid molecular fractions on growth and development of soybean seedlings under salt stress. Plant Growth Regul. 2017, 83, 465-477. [CrossRef]

98. Lawson, I.Y.D.; Hayatsu, M.; Nioh, I. Effects of compost application on growth and nodulation of kidney bean, soybean and alfalfa under salt stress. West Afr. J. Appl. Ecol. 2004, 5, 1-9. [CrossRef]

99. Sun, H.; Lu, H.; Chu, L.; Shao, H.; Shi, W. Biochar applied with appropriate rates can reduce N leaching, keep $\mathrm{N}$ retention and not increase $\mathrm{NH}_{3}$ volatilization in a coastal saline soil. Sci. Total Environ. 2017, 575, 820-825. [CrossRef]

100. EL Sabagh, A.; Sobhy, S.; Akram, M.; Mohammad, S.I.; Akihiro, U.; Celaleddin, B.; Halis, A.; Hirofumi, S. Role of osmoprotectants and compost application in improving water stress tolerance insoybean (Glycine max L.). Int. J. Curr. Res. 2016, 8, 25949-25954. 
101. Matijeví, L.; Romí, D.; Romí, M.; Mauroví, N.; Kondres, N. Faba bean (Vicia faba L.) salt stress response under different soil organic matter content. Agric. Conspec. Sci. 2014, 79, 13-18.

102. Garg, N.; Chandel, S. Effect of mycorrhizal inoculation on growth, nitrogen fixation, and nutrient uptake in Cicer arietinum (L.) under salt stress. Turk. J. Agric. For. 2011, 35, 205-214. [CrossRef]

103. Kabir, M.E.; Karim, M.A.; Azad, M.A.K. Effect of potassium on salinity tolerance of mungbean (Vigana radiata L. Wilczek). J. Biol. Sci. 2004, 4, 103-110.

104. Guo, J.S.; Zhou, Q.; Li, X.J.; Yu, B.J.; Luo, Q.Y. Enhancing $\mathrm{NO}_{3}$ - supply confers $\mathrm{NaCl}$ tolerance by adjusting Cl-uptake and transport in G. max \& G. soja. J. Soil Sci. Plant Nutr. 2017, 17, 194-204.

105. El-Nour, A.A.A. Can supplemented potassium foliar feeding reduce the recommended soil potassium. Pak. J. Biol. Sci. 2002, 5, 259-262. [CrossRef]

106. Abou-El-Nour, E.Z.A.; Aly, E.M.; El-Fouly, M.M.; Salama, Z.A.E.R. Chelated Fe and Zn foliar spray improve the tolerance of kidney bean (var. nebraska) plants in salinized media. Biosci. Res. 2017, 14, 525-531.

107. Zuccarini, P. Effects of silicon on photosynthesis, water relations and nutrient uptake of Phaseolus vulgaris under $\mathrm{NaCl}$ stress. Biol. Plant. 2008, 52, 157-160. [CrossRef]

108. Kardoni, F.; Jalil, S.; Seyyed Mosavi, S.J.; Parande, S. Effect of salinity stress and silicon application on yield and component yield offaba bean (Vicia faba). Int. J. Agric. Crop Sci. 2013, 6, 814-818.

109. Murtaza, G.; Ghafoor, A.; Qadir, M. Irrigation and soil management strategies for using saline-sodic water in a cotton-wheat rotation. Agric. Water Manag. 2006, 81, 98-114. [CrossRef]

110. Yamika, W.S.D.; Aini, N.; Setiawan, A.; Purwaningrahayu, R.D. Effect of gypsum and cow manure on yield, proline content, and K/Na ratio of soybean genotypes under saline conditions. J. Degrad. Min. Lands Manag. 2018, 5, 1047-1053. [CrossRef]

111. Hussain, S.; Zhang, J.; Zhong, C.; Zhu, L.; Cao, X.; Yu, S.; Allen, B.J.; Hu, J.; Jin, Q. Effects of salt stress on rice growth, development characteristics, and the regulating ways: A review. J. Integr. Agric. 2017, 16, 2357-2374. [CrossRef]

112. Abdel-Fattah, M.K. Role of gypsum and compost in reclaiming saline-sodic soils. IOSR J. Agric. Vet. Sci. 2012, 1, 30-38. [CrossRef]

113. Thakuria, D.; Hazarika, S.; Krishnappa, R. Soil acidity and management options. Indian J. Fertil. 2016, 12, $40-56$.

114. Han, H.; Lee, S. Physiological responses of soybean inoculation of Bradyrhizobium japonicum with PGPR in saline soil conditions. Res. J. Agric. Biol. Sci. 2005, 1, 216-221.

115. Egamberdieva, D. Survival of Pseudomonas extremorientalis TSAU20 and P. chlororaphis TSAU13 in the rhizosphere of common bean (Phaseolus vulgaris) under saline conditions. Plant Soil Environ. 2011, 57, 122-127. [CrossRef]

116. Egamberdiyeva, D.; Höflich, G. Root colonization and growth promotion of winter wheat and pea by Cellulomonas spp. at different temperatures. Plant Growth Regul. 2002, 38, 219-224. [CrossRef]

117. Afolayan, E.T.; Eguavon, M.I. Morphological and yield assessment of soybean (Glycine max L.) as influenced by arbuscular mycorrhizal fungi and other soil amendments. J. Agric. Sci. Food Res. 2017, 8, 1-5.

118. Metwali, E.M.R.; Abdelmoneim, T.S.; Bakheit, M.A.; Kadasa, N.M.S. Alleviation of salinity stress in faba bean (Vicia faba L.) plants by inoculation with plant growth promoting rhizobacteria (PGPR). Plant Omics 2015, 8, 449-460.

119. Chaudhary, D.; Sindhu, S. Inducing salinity tolerance in chickpea (Cicer arietinum L.) by inoculation of 1-aminocyclopropane-1-carboxylic acid deaminase-containing Mesorhizobium strains. Afr. J. Microbiol. Res. 2015, 9, 117-124. [CrossRef]

120. Valverde, A.; Velázquez, E.; Fernández-Santos, F.; Vizcaíno, N.; Mateos, P.F.; Martínez-Molina, E.; Igual, J.M.; Willems, A. Phyllobacterium trifolii sp. nov., nodulating Trifolium and Lupinas in Spanish soils. Int. J. Syst. Evol. Microbiol. 2005, 55, 1985-1989. [CrossRef]

121. Yadegari, M.; Rahmani, H.A.; Noormohammadi, G.; Ayneband, A. Evaluation of bean (Phaseolus vulgaris) seeds inoculation with Rhizobium phaseoli and plant growth promoting rhizobacteria on yield and yield components. Pak. J. Biol. Sci. 2010, 5, 792-799. [CrossRef]

122. Ahmad, M.; Zahir, Z.; Asghar, H.; Arshad, M. The combined application of rhizobial strains and plant growth promoting rhizobacteria improves growth and productivity of mung bean (Vigna radiata L.) under salt-stressed conditions. Ann. Microbiol. 2012, 62, 1321-1330. [CrossRef] 
123. Ahmad, M.; Zahir, Z.A.; Asghar, H.N.; Asghar, M. Inducing salt tolerance in mung bean through coinoculation with Rhizobia and plant-growth-promoting rhizobacteria containing 1-aminocyclopropane-1-carboxylate deaminase. Can. J. Microbiol. 2011, 57, 578-589. [CrossRef] [PubMed]

124. Ahmad, M.; Zahir, Z.A.; Khalid, M.; Nazli, F.; Arshad, M. Efficacy of Rhizobium and Pseudomonas strains to improve physiology, ionic balance and quality of mungbean under salt-affected conditions on farmer's fields. Plant Physiol. Biochem. 2013, 63, 170-176. [CrossRef] [PubMed]

125. Penrose, D.M.; Moffatt, B.A.; Glick, B.R. Determination of 1-aminocycopropane-1-carboxylic acid (ACC) to assess the effects of ACC deaminase-containing bacteria on roots of canola seedlings. Can. J. Microbiol. 2001, 47, 77-80. [CrossRef] [PubMed]

126. Pliego, C.; Kamilova, F.; Lugtenberg, B. Plant Growth-Promoting Bacteria: Fundamentals and Exploitation. In Bacteria in Agrobiology: Crop Ecosystems; Maheshwari, D.K., Ed.; Springer: Heidelberg/Berlin, Germany, 2011; ISBN 978-3-642-18356-0.

127. Paparella, S.; Araújo, S.S.; Rossi, G.; Wijayasinghe, M.; Carbonera, D.; Balestrazzi, A. Seed priming: State of the art and new perspectives. Plant Cell Rep. 2015, 34, 1281-1293. [CrossRef] [PubMed]

128. Ibrahim, E.A. Seed priming to alleviate salinity stress in germinating seeds. J. Plant Physiol. 2016, 192, 38-46. [CrossRef] [PubMed]

129. Hussain, S.; Khan, F.; Hussain, H.A.; Nie, L. Physiological and biochemical mechanisms of seed priming-induced chilling tolerance in rice cultivars. Front. Plant Sci. 2016, 7, 1-14. [CrossRef]

130. Dai, L.-Y.; Zhu, H.-D.; Yin, K.-D.; Du, J.-D.; Zhang, Y.-X. Seed priming mitigates the effects of saline-alkali stress in soybean seedlings. Chil. J. Agric. Res. 2017. [CrossRef]

131. Harris, D.; Rashid, A.; Miraj, G. 'On-farm' seed priming with zinc in chickpea and wheat in Pakistan 'On-farm' seed priming with zinc in chickpea and wheat in Pakistan. Plant Soil 2007. [CrossRef]

132. Younesi, O.; Moradi, A. Effect of priming of seeds of m edicago sativa 'bami' with gibberellic acid on germination, seedlings growth and antioxidant enzymes activity under salinity stress. J. Hortic. Res. 2014, 22, 167-174. [CrossRef]

133. Azooz, M.M. Salt Stress Mitigation by seed priming with salicylic acid in two faba bean salt stress mitigation by seed priming with salicylic acid in two faba bean genotypes differing in salt tolerance. Int. J. Agric. Biol. 2009, 11, 343-350.

134. Jisha, K.C.; Puthur, J.T. Halopriming of seeds imparts tolerance to $\mathrm{NaCl}$ and PEG induced stress in (Vigna radiata L.) Wilczek varieties. Physiol. Mol. Biol. Plants 2014, 20, 303-312. [CrossRef] [PubMed]

135. Sarwar, N.; Yousaf, S.; Jamil, F.F. Induction of salt tolerance in chickpea by using simple and safe chemicals. Pak. J. Bot. 2006, 38, 325-329.

136. Ahmadvand, G.; Soleimani, F.; Saadatian, B.; Pouya, M. Effects of seed priming on germination and emergence traits of two soybean cultivars under salinity stress. J. Basic Appl. Sci. Res. 2012, 3, 234-241.

137. Khomari, S.; Golshan-doust, S.; Seyed-sharifi, R.; Davari, M. Improvement of soybean seedling growth under salinity stress by biopriming of high-vigour seeds with salt-tolerant isolate of Trichoderma harzianum. N. Z. J. Crop Hortic. Sci. 2017, 00, 1-16. [CrossRef]

138. Abdolahpour, M.; Lotfi, R. Seed priming affected physiology and grain yield of chickpea under salt stress. J. Biodivers. Environ. Sci. 2014, 5, 442-446.

139. Hussain, S.S.; Ali, M.; Ahmad, M.; Siddique, K.H.M. Polyamines: Natural and engineered abiotic and biotic stress tolerance in plants. Biotechnol. Adv. 2011, 29, 300-311. [CrossRef]

140. Berberich, T.K.T.; Takahashi, C.T.Y. Polyamines: Essential factors for growth and survival. Planta 2008, 228, 367-381. [CrossRef]

141. Gupta, K.; Dey, A.; Gupta, B.; Bengal, W. Plant polyamines in abiotic stress responses. Acta Physiol. Plant. 2013, 35, 2015-2036. [CrossRef]

142. Silveira, V.; Martins, A.; Ferreira, A.; Maria, M.; Ribeiro, F.; Iochevet, E.; Floh, S. Morphological and polyamine content changes in embryogenic and non-embryogenic callus of sugarcane. Plant Cell Tissue Organ Cult. 2013, 114, 351-364. [CrossRef]

143. Gomez-jimenez, J.A.G.M.C. Regulation of polyamine metabolism and biosynthetic gene expression during Regulation of polyamine metabolism and biosynthetic gene expression during olive mature-fruit abscission. Planta 2012, 235, 1221-1237. [CrossRef] 
144. Kim, N.H.; Kim, B.S.; Hwang, B.K. Pepper arginine decarboxylase is required for polyamine and g-Aminobutyric acid signaling in cell death and defense response. Plant Physiol. 2013, 162, 2067-2083. [CrossRef] [PubMed]

145. Tisi, A.; Federico, R.; Moreno, S.; Lucretti, S.; Moschou, P.N.; Roubelakis-Angelakis, K.A.; Angelini, R.; Cona, A. Perturbation of polyamine catabolism can strongly affect root development and xylem differentiation. Plant Physiol. 2011, 157, 200-215. [CrossRef] [PubMed]

146. Zhang, G.-W.; Xu, S.-C..; Hu, Q.-Z.; Mao, W.-H.; Gong, Y.-M. Putrescine plays a positive role in salt-tolerance mechanisms by reducing oxidative damage in roots of vegetable soybean. J. Integr. Agric. 2014, 13, 349-357. [CrossRef]

147. Sheokand, S.; Kumari, A.; Sawhney, V. Effect of nitric oxide and putrescine on antioxidative responses under $\mathrm{NaCl}$ stress in chickpea plants. Physiol. Mol. Biol. Plants 2008, 14, 355-362. [CrossRef] [PubMed]

148. Suleiman, S. Effects of exogenous application of diamine (Putrescine) on growth and mineral elements distribution in faba bean plants under saline conditions. Biol. Sci. Ser. 2008, 2008. 30, 258-265.

149. Mahdi, A.H.A. Improvement of salt tolerance in Vicia faba (L.) plants by exogenous application of polyamines. Egypt. J. Agron. 2016, 38, 1-21.

150. Radhakrishnan, R.; Lee, I.-J. Spermine promotes acclimation to osmotic stress by modifying antioxidant, abscisic acid, and jasmonic acid signals in soybean. J. Plant Growth Regul. 2012, 32, 22-30. [CrossRef]

151. Lou, Y.; Guan, R.; Sun, M.; Han, F.; He, W.; Wang, H.; Song, F.; Cui, X.; Zhuge, Y. Spermidine application alleviates salinity damage to antioxidant enzyme activity and gene expression in alfalfa. Ecotoxicology 2018. [CrossRef]

152. Nahar, K.; Hasanuzzaman, M.; Rahman, A.; Alam, M. Polyamines confer salt tolerance in mungbean (Vigna radiata L.) by reducing sodium uptake, improving nutrient homeostasis, antioxidant defense, and methylglyoxal detoxification systems. Front. Plant Sci. 2016, 7, 1-14. [CrossRef]

153. Ghosh, S.; Mitra, S.; Paul, A. Physiochemical studies of sodium chloride on mungbean (Vigna radiata L. Wilczek) and its possible recovery with spermine and gibberellic acid. Sci. World J. 2015, 2015. [CrossRef]

154. Smýkal, P.; Coyne, C.J.; Ambrose, M.J.; Maxted, N.; Schaefer, H.; Blair, M.W.; Berger, J.; Greene, S.L.; Nelson, M.N.; Besharat, N.; et al. Legume crops phylogeny and genetic diversity for science and breeding. Crit. Rev. Plant Sci. 2015, 34, 43-104. [CrossRef]

155. Duc, G.; Agrama, H.; Bao, S.; Berger, J.; Bourion, V.; De Ron, A.M.; Gowda, C.L.L.; Mikic, A.; Millot, D.; Singh, K.B.; et al. Breeding annual grain legumes for sustainable agriculture: New methods to approach complex traits and target new cultivar ideotypes. Crit. Rev. Plant Sci. 2015, 34, 381-411. [CrossRef]

156. Sehrawat, N.; Bhat, K.V.; Kaga, A.; Tomooka, N.; Yadav, M.; Jaiwal, P.K. Development of new gene-specific markers associated with salt tolerance for mungbean (Vigna radiata L. Wilczek). Span. J. Agric. Res. 2014, 12, 732-741. [CrossRef]

157. Sharma, S.; Upadhyaya, H.D.; Varshney, R.K.; Gowda, C.L.L. Pre-breeding for diversification of primary gene pool and genetic enhancement of grain legumes. Front. Plant Sci. 2013, 4. [CrossRef] [PubMed]

158. Foolad, M.R. Recent advances in genetics of salt tolerance in tomato. Plant Cell Tissue Organ Cult. 2004, 76, 101-119. [CrossRef]

159. Dita, M.A.; Rispail, N.; Prats, E.; Rubiales, D.; Singh, K.B. Biotechnology approaches to overcome biotic and abiotic stress constraints in legumes. Euphytica 2006, 147, 1-24. [CrossRef]

160. Lee, G.J.; Boerma, H.R.; Villagarcia, M.R.; Zhou, X.; Carter, T.E.; Li, Z.; Gibbs, M.O. A major QTL conditioning salt tolerance in S-100 soybean and descendent cultivars. Theor. Appl. Genet. 2004, 109, 1610-1619. [CrossRef]

161. Vadez, V.; Krishnamurthy, L.; Thudi, M.; Anuradha, C.; Timothy, D.; Turner, N.C.; Siddique, K.H.M.; Gaur, P.M.; Varshney, R.K.; Vadez, V.; et al. Assessment of ICCV $2 \times$ JG 62 chickpea progenies shows sensitivity of reproduction to salt stress and reveals QTL for seed yield and yield components. Mol. Breed. 2012, 30, 9-21. [CrossRef]

162. Leonforte, A.; Sudheesh, S.; Cogan, N.O.I.; Salisbury, P.A.; Nicolas, M.E.; Materne, M.; Forster, J.W.; Kaur, S. SNP marker discovery, linkage map construction and identification of QTL for enhanced salinity tolerance in field pea (Pisum satioum L.). BMC Plant Biol. 2013, 13, 161. [CrossRef]

163. Samineni, S. Genetics and QTL Mapping of Salt Tolerance in Chickpea (Cicer arietinum L.). Ph.D. Thesis, University of Western Australia, Perth, Australia, 2010. 
164. Shi, X.; Yan, L.; Yang, C.; Yan, W.; Moseley, D.O.; Wang, T.; Liu, B.; Di, R.; Chen, P.; Zhang, M. Identification of a major quantitative trait locus underlying salt tolerance in 'Jidou 12 ' soybean cultivar. BMC Res. Notes 2018, 1-6. [CrossRef] [PubMed]

165. Chankaew, S.; Isemura, T.; Naito, K.; Kaga, A.; Vaughan, D.A.; Srinives, P. QTL mapping for salt tolerance and domestication related traits in Vigna marina subsp. oblonga, a halophytic species. Theor. Appl. Genet. 2014, 127, 691-702. [CrossRef] [PubMed]

166. Ashraf, M.; Foolad, M.R. Crop breeding for salt tolerance in the era of molecular markers and marker-assisted selection. Plant Breed. 2012, 132, 10-20. [CrossRef]

167. Guan, R.; Chen, J.; Jiang, J.; Liu, G.; Liu, Y.; Tian, L.; Yu, L.; Chang, R.; Qiu, L.-J. Mapping and validation of a dominant salt tolerance gene in the cultivated soybean (Glycine max L.) variety Tiefeng 8. Crop J. 2014, 2, 358-365. [CrossRef]

168. Hamwieh, A.; Tuyen, D.D.; Cong, H.; Benitez, E.R.; Takahashi, R.; Xu, D.H. Identification and validation of a major QTL for salt tolerance in soybean. Euphytica 2011, 179, 451-459. [CrossRef]

169. Kumar, J.; Choudhary, A.K.; Solanki, R.K.; Pratap, A. Towards marker-assisted selection in pulses: A review. Plant Breed. 2011, 130, 297-313. [CrossRef]

170. Pandiyan, M.; Senthil, N.; Packiaraj, D.; Gupta, S.; Nadarajan, N.; Pandian, R.T.; Suresh, R.; Jagadeesh, S. Characterisation and evaluation of 646 greengram (Vigna radiata) genotypes for constituting core collection. Wudpecker J. Agric. Res. 2012, 1, 294-301.

171. Nirmala, S.; Mukesh, Y.; Venkataraman, B.K.; Kumar, S.R.; Kumar, J.P. Hybridization between salt resistant and salt susceptible genotypes of mungbean (Vigna radiata L. Wilczek) and purity testing of the hybrids using SSRs markers. J. Integr. Agric. 2016, 15, 521-527. [CrossRef]

172. Covarrubias, A.A.; Reyes, J.L. Post-transcriptional gene regulation of salinity and drought responses by plant microRNAs. Plant Cell Environ. 2010, 33, 481-489. [CrossRef]

173. Dong, Z.; Shi, L.; Wang, Y.; Chen, L.; Cai, Z.; Wang, Y.; Jin, J.; Li, X. Identification and dynamic regulation of microRNAs involved in salt stress responses in functional soybean nodules by high-throughput sequencing. Int. J. Mol. Sci. 2013, 14, 2717-2738. [CrossRef]

174. Liao, Y.; Zou, H.F.; Wang, H.W.; Zhang, W.K.; Ma, B.; Zhang, J.S.; Chen, S.Y. Soybean GmMYB76, GmMYB92, and GmMYB177 genes confer stress tolerance in transgenic Arabidopsis plants. Cell Res. 2008, 18, 1047-1060. [CrossRef]

175. Liu, Y.; Yu, L.; Qu, Y.; Chen, J.; Liu, X.; Hong, H.; Liu, Z.; Chang, R.; Gilliham, M.; Qiu, L.; et al. GmSALT3, which confers improved soybean salt tolerance in the field, increases leaf $\mathrm{Cl}^{-}$exclusion prior to $\mathrm{Na}^{+}$exclusion but does not improve early vigor under salinity. Front. Plant Sci. 2016, 7, 1-14. [CrossRef] [PubMed]

176. Guan, R.; Qu, Y.; Guo, Y.; Yu, L.; Liu, Y.; Jiang, J.; Chen, J.; Ren, Y.; Liu, G.; Tian, L.; et al. Salinity tolerance in soybean is modulated by natural variation in GmSALT3. Plant J. 2014, 80, 937-950. [CrossRef] [PubMed]

177. Xue, C.C.; Xu, J.Y.; Wang, C.; Guo, N.; Hou, J.F.; Xue, D.; Zhao, J.M.; Xing, H. Molecular cloning and functional characterization of a soybean GmGMP1 gene reveals its involvement in ascorbic acid biosynthesis and multiple abiotic stress tolerance in transgenic plants. J. Integr. Agric. 2018, 17, 539-553. [CrossRef]

178. Chen, Y.; Chi, Y.; Meng, Q.; Wang, X.; Yu, D. GmSK1, an SKP1 homologue in soybean, is involved in the tolerance to salt and drought. Plant Physiol. Biochem. 2018, 127, 25-31. [CrossRef] [PubMed]

179. Li, M.; Hu, Z.; Jiang, Q.Y.; Sun, X.J.; Guo, Y.; Qi, J.C.; Zhang, H. GmNAC15 overexpression in hairy roots enhances salt tolerance in soybean. J. Integr. Agric. 2018, 17, 530-538. [CrossRef]

180. An, J.; Cheng, C.; Hu, Z.; Chen, H.; Cai, W.; Yu, B. The Panax ginseng PgTIP1 gene confers enhanced salt and drought tolerance to transgenic soybean plants by maintaining homeostasis of water, salt ions and ROS. Environ. Exp. Bot. 2018, 155, 45-55. [CrossRef]

181. Wang, L.S.; Chen, Q.S.; Xin, D.W.; Qi, Z.M.; Zhang, C.; Li, S.N.; Jin, Y.M.; Li, M.; Mei, H.Y.; Su, A.Y.; et al. Overexpression of GmBIN2, a soybean glycogen synthase kinase 3 gene, enhances tolerance to salt and drought in transgenic Arabidopsis and soybean hairy roots. J. Integr. Agric. 2018, 17, 1959-1971. [CrossRef]

182. Pruthvi, V.; Narasimhan, R.; Nataraja, K.N. Simultaneous expression of abiotic stress responsive transcription factors, AtDREB2A, AtHB7 and AtABF3 improves salinity and drought tolerance in peanut (Arachis hypogaea L.). PLoS ONE 2014, 9, 1-21. [CrossRef]

183. Lopez, C.M.L.; Takahashi, H.; Yamazaki, S. Plant-water relations of kidney bean plants treated with $\mathrm{NaCl}$ and foliarly applied glycinebetaine. J. Agron. Crop Sci. 2002, 188, 73-80. [CrossRef] 
184. Frugier, F.; Poirier, S.; Satiat-Jeunemaître, B.; Kondorosi, A.; Crespi, M. A Kruppel-like zinc finger protein is involved in nitrogen-fixing root nodule organogenesis. Genes Dev. 2000, 14, 475-482. [CrossRef] [PubMed]

185. Hanafy, M.S.; El-Banna, A.; Schumacher, H.M.; Jacobsen, H.J.; Hassan, F.S. Enhanced tolerance to drought and salt stresses in transgenic faba bean (Vicia faba L.) plants by heterologous expression of the PR10a gene from potato. Plant Cell Rep. 2013, 32, 663-674. [CrossRef] [PubMed]

186. Bai, X.; Liu, J.; Tang, L.; Cai, H.; Chen, M.; Ji, W.; Liu, Y.; Zhu, Y. Overexpression of GsCBRLK from Glycine soja enhances tolerance to salt stress in transgenic alfalfa (Medicago sativa). Funct. Plant Biol. 2013, 40, 1048-1056. [CrossRef]

187. Ji, W.; Koh, J.; Li, S.; Zhu, N.; Dufresne, C.P.; Zhao, X.; Chen, S.; Li, J. Quantitative proteomics reveals an important role of GsCBRLK in salt stress response of soybean. Plant Soil 2016, 402, 159-178. [CrossRef]

188. Cao, D.; Hou, W.; Liu, W.; Yao, W.; Wu, C.; Liu, X.; Han, T. Overexpression of TaNHX2 enhances salt tolerance of "composite" and whole transgenic soybean plants. Plant Cell. Tissue Organ Cult. 2011, 107, 541-552. [CrossRef]

189. Bao, A.K.; Wang, S.M.; Wu, G.Q.; Xi, J.J.; Zhang, J.L.; Wang, C.M. Overexpression of the Arabidopsis $\mathrm{H}^{+}$-PPase enhanced resistance to salt and drought stress in transgenic alfalfa (Medicago sativa L.). Plant Sci. 2009, 176, 232-240. [CrossRef]

190. De Zélicourt, A.; Diet, A.; Marion, J.; Laffont, C.; Ariel, F.; Moison, M.; Zahaf, O.; Crespi, M.; Gruber, V.; Frugier, F. Dual involvement of a Medicago truncatula NAC transcription factor in root abiotic stress response and symbiotic nodule senescence. Plant J. 2012, 70, 220-230. [CrossRef]

191. Tripathi, P.; Rabara, R.C.; Rushton, P.J. A systems biology perspective on the role of WRKY transcription factors in drought responses in plants. Planta 2014, 239, 255-266. [CrossRef]

192. Yu, X.; Liu, Y.; Wang, S.; Tao, Y.; Wang, Z.; Shu, Y.; Peng, H.; Mijiti, A.; Wang, Z.; Zhang, H.; et al. CarNAC4, a NAC-type chickpea transcription factor conferring enhanced drought and salt stress tolerances in Arabidopsis. Plant Cell Rep. 2016, 35, 613-627. [CrossRef]

193. Sarkar, T.; Thankappan, R.; Kumar, A.; Mishra, G.P. Heterologous expression of the AtDREB1A gene in transgenic peanut-conferred tolerance to drought and salinity stresses. PLoS ONE 2014, 9, 1-25. [CrossRef]

194. Khatib, F.; Makris, A.; Yamaguchi-Shinozaki, K.; Kumar, S.; Sarker, A.; Erskine, W.; Baum, M. Expression of the DREB1A gene in lentil (Lens culinaris Medik. subsp. culinaris) transformed with the Agrobacterium system. Crop Pasture Sci. 2011, 62, 488-495. [CrossRef]

195. Singh, R.J.; Chung, G.H.; Nelson, R.L. Landmark research in legumes. Genome 2007, 50, 525-537. [CrossRef]

196. Zuryn, S.; Le Gras, S.; Jamet, K.; Jarriault, S. A strategy for direct mapping and identification of mutations by whole-genome sequencing. Genetics 2010, 186, 427-430. [CrossRef] [PubMed]

197. Kudapa, H.; Ramalingam, A.; Nayakoti, S.; Chen, X.; Zhuang, W.J.; Liang, X.; Kahl, G.; Edwards, D.; Varshney, R.K. Functional genomics to study stress responses in crop legumes: Progress and prospects. Funct. Plant Biol. 2013, 40, 1221-1233. [CrossRef]

198. O’Rourke, J.A.; Bolon, Y.T.; Bucciarelli, B.; Vance, C.P. Legume genomics: Understanding biology through DNA and RNA sequencing. Ann. Bot. 2014, 113, 1107-1120. [CrossRef] [PubMed]

199. Pandey, M.K.; Roorkiwal, M.; Singh, V.K.; Ramalingam, A.; Kudapa, H.; Thudi, M.; Chitikineni, A.; Rathore, A.; Varshney, R.K. Emerging genomic tools for legume breeding: Current status and future prospects. Front. Plant Sci. 2016, 7, 1-18. [CrossRef] [PubMed]

200. Zhang, G.C.; Zhu, W.L.; Gai, J.Y.; Zhu, Y.L.; Yang, L.F. Enhanced salt tolerance of transgenic vegetable soybeans resulting from overexpression of a novel $\Delta 1$-pyrroline-5-carboxylate synthetase gene from Solanum torvum Swartz. Hortic. Environ. Biotechnol. 2015, 56, 94-104. [CrossRef]

201. Wang, Y.; Jiang, L.; Chen, J.; Tao, L.; An, Y.; Cai, H.; Guo, C. Overexpression of the alfalfa WRKY11 gene enhances salt tolerance in soybean. PLoS ONE 2018, 13, 1-16. [CrossRef]

202. Ali, Z.; Ullah, N.; Naseem, S.; Inam-Ul-Haq, M.; Jacobsen, H.J. Soil bacteria conferred a positive relationship and improved salt stress tolerance in transgenic pea (Pisum sativum L.) harboring $\mathrm{Na}^{+} / \mathrm{H}^{+}$antiporter. Turk. J. Botany 2015, 39, 962-972. [CrossRef]

203. Najafi, F.; Rastgar-jazii, F.; Khavari-Nejad, R.A.; Sticklen, M. Salt tolerance in transgenic pea (Pisum sativum L.) plants by P5CS gene transfer. J. Plant Biotechnol. 2005, 7, 233-240.

204. Kiran Kumar Ghanti, S.; Sujata, K.G.; Vijay Kumar, B.M.; Nataraja Karba, N.; Janardhan Reddy, K.; Srinath Rao, M.; Kavi Kishor, P.B. Heterologous expression of P5CS gene in chickpea enhances salt tolerance without affecting yield. Biol. Plant. 2011, 55, 634-640. [CrossRef] 
205. Bhomkar, P.; Upadhyay, C.P.; Saxena, M.; Muthusamy, A.; Shiva Prakash, N.; Pooggin, M.; Hohn, T.; Sarin, N.B. Salt stress alleviation in transgenic Vigna mungo L. Hepper (blackgram) by overexpression of the glyoxalase I gene using a novel Cestrum yellow leaf curling virus (CmYLCV) promoter. Mol. Breed. 2008, 22, 169-181. [CrossRef]

206. Surekha, C.; Kumari, K.N.; Aruna, L.V.; Suneetha, G.; Arundhati, A.; Kavi Kishor, P.B. Expression of the Vigna aconitifolia P5CSF129A gene in transgenic pigeonpea enhances proline accumulation and salt tolerance. Plant Cell. Tissue Organ Cult. 2014, 116, 27-36. [CrossRef]

207. Bhatnagar-Mathur, P.; Vadez, V.; Jyostna Devi, M.; Lavanya, M.; Vani, G.; Sharma, K.K. Genetic engineering of chickpea (Cicer arietinum L.) with the P5CSF129A gene for osmoregulation with implications on drought tolerance. Mol. Breed. 2009, 23, 591-606. [CrossRef]

208. Banjara, M.; Zhu, L.; Shen, G.; Payton, P.; Zhang, H. Expression of an Arabidopsis sodium/proton antiporter gene (AtNHX1) in peanut to improve salt tolerance. Plant Biotechnol. Rep. 2012, 6, 59-67. [CrossRef]

209. Banavath, J.N.; Chakradhar, T.; Pandit, V.; Konduru, S.; Guduru, K.K.; Akila, C.S.; Podha, S.; Puli, C.O.R. Stress Inducible Overexpression of AtHDG11 leads to improved drought and salt stress tolerance in peanut (Arachis hypogaea L.). Front. Chem. 2018, 6, 34. [CrossRef] [PubMed]

210. Li, W.; Wang, D.; Jin, T.; Chang, Q.; Yin, D.; Xu, S.; Liu, B.; Liu, L. The Vacuolar $\mathrm{Na}^{+} / \mathrm{H}^{+}$antiporter gene SsNHX1 from the halophyte salsola soda confers salt tolerance in transgenic alfalfa (Medicago sativa L.). Plant Mol. Biol. Report. 2011, 29, 278-290. [CrossRef]

211. Duan, Z.; Zhang, D.; Zhang, J.; Di, H.; Wu, F.; Hu, X.; Meng, X.; Luo, K.; Zhang, J.; Wang, Y. Co-transforming bar and $C s A L D H$ genes enhanced resistance to herbicide and drought and salt stress in transgenic alfalfa (Medicago sativa L.). Front. Plant Sci. 2015, 6, 1-9. [CrossRef] [PubMed]

212. Jin, T.; Chang, Q.; Li, W. Stress-inducible expression of GmDREB1 conferred salt tolerance in transgenic alfalfa. Plant Cell Tissue Organ Cult. 2010, 100, 219-227. [CrossRef]

213. Wang, Z.; Ke, Q.; Kim, M.D.; Kim, S.H.; Ji, C.Y. Transgenic alfalfa plants expressing the sweetpotato orange gene exhibit enhanced abiotic stress tolerance. PLoS ONE 2015, 10, 1-17. [CrossRef]

214. Zhang, Y.M.; Liu, Z.H.; Wen, Z.Y.; Zhang, H.M.; Yang, F.; Guo, X.L. The vacuolar $\mathrm{Na}^{+} / \mathrm{H}^{+}$antiport gene TaNHX2 confers salt tolerance on transgenic alfalfa (Medicago sativa L.). Funct. Plant Biol. 2012, 39, 708-716. [CrossRef]

215. Liu, L.; Fan, X.D.; Wang, F.W.; Wang, N.; Dong, Y.Y.; Liu, X.M.; Yang, J.; Wang, Y.F.; Li, H.Y. Coexpression of ScNHX1 and ScVP in transgenic hybrids improves salt and saline-alkali tolerance in alfalfa (Medicago sativa L.). J. Plant Growth Regul. 2013, 32, 1-8. [CrossRef]

216. Tang, L.; Cai, H.; Ji, W.; Luo, X.; Wang, Z.; Wu, J.; Wang, X.; Cui, L.; Wang, Y.; Zhu, Y.; et al. Overexpression of GsZFP1 enhances salt and drought tolerance in transgenic alfalfa (Medicago sativa L.). Plant Physiol. Biochem. 2013, 71, 22-30. [CrossRef] [PubMed]

217. Mickelbart, M.V.; Hasegawa, P.M.; Bailey-Serres, J. Genetic mechanisms of abiotic stress tolerance that translate to crop yield stability. Nat. Rev. Genet. 2015, 16, 237-251. [CrossRef] [PubMed]

218. Jain, M. Function genomics of abiotic stress tolerance in plants: A CRISPR approach. Front. Plant Sci. 2015, 6, 2011-2014. [CrossRef] [PubMed]

219. Kumar, V.; Jain, M. The CRISPR-Cas system for plant genome editing: Advances and opportunities. J. Exp. Bot. 2015, 66, 47-57. [CrossRef]

220. Jaganathan, D.; Ramasamy, K.; Sellamuthu, G.; Jayabalan, S.; Venkataraman, G. CRISPR for Crop Improvement: An Update Review. Front. Plant Sci. 2018, 9, 1-17. [CrossRef]

221. Huang, L.; Zhang, R.; Huang, G.; Li, Y.; Melaku, G.; Zhang, S.; Chen, H.; Zhao, Y.; Zhang, J.; Zhang, Y.; et al. Developing superior alleles of yield genes in rice by artificial mutagenesis using the CRISPR/Cas9 system. Crop J. 2018, 6, 475-481. [CrossRef]

222. Wang, Y.; Cheng, X.; Shan, Q.; Zhang, Y.; Liu, J.; Gao, C.; Qiu, J.L. Simultaneous editing of three homoeoalleles in hexaploid bread wheat confers heritable resistance to powdery mildew. Nat. Biotechnol. 2014, 32, 947-951. [CrossRef]

223. Sánchez-León, S.; Gil-Humanes, J.; Ozuna, C.V.; Giménez, M.J.; Sousa, C.; Voytas, D.F.; Barro, F. Low-gluten, nontransgenic wheat engineered with CRISPR/Cas9. Plant Biotechnol. J. 2018, 16, 902-910. [CrossRef]

224. Zhu, J.; Song, N.; Sun, S.; Yang, W.; Zhao, H.; Song, W.; Lai, J. Efficiency and inheritance of targeted mutagenesis in maize using CRISPR-Cas9. J. Genet. Genom. 2016, 43, 25-36. [CrossRef] 
225. Agarwal, A.; Yadava, P.; Kumar, K.; Singh, I.; Kaul, T.; Pattanayak, A.; Agrawal, P.K. Insights into maize genome editing via CRISPR/Cas9. Physiol. Mol. Biol. Plants 2018, 24, 175-183. [CrossRef]

226. Lawrenson, T.; Shorinola, O.; Stacey, N.; Li, C.; Østergaard, L.; Patron, N.; Uauy, C.; Harwood, W. Induction of targeted, heritable mutations in barley and Brassica oleracea using RNA-guided Cas9 nuclease. Genome Biol. 2015, 16, 1-13. [CrossRef] [PubMed]

227. Kapusi, E.; Corcuera-Gómez, M.; Melnik, S.; Stoger, E. Heritable genomic fragment deletions and small indels in the Putative ENGase gene induced by CRISPR/Cas9 in barley. Front. Plant Sci. 2017, 8, 1-11. [CrossRef]

228. Nakayasu, M.; Akiyama, R.; Lee, H.J.; Osakabe, K.; Osakabe, Y.; Watanabe, B.; Sugimoto, Y.; Umemoto, N.; Saito, K.; Muranaka, T.; et al. Generation of $\alpha$-solanine-free hairy roots of potato by CRISPR/Cas9 mediated genome editing of the St16DOX gene. Plant Physiol. Biochem. 2018, 131, 70-77. [CrossRef]

229. Jia, H.; Nian, W. Targeted genome editing of sweet orange using Cas9/sgRNA. PLoS ONE 2014, 9. [CrossRef] [PubMed]

230. Jacobs, T.B.; LaFayette, P.R.; Schmitz, R.J.; Parrott, W.A. Targeted genome modifications in soybean with CRISPR/Cas9. BMC Biotechnol. 2015, 15, 1-10. [CrossRef] [PubMed]

231. Li, Z.; Liu, Z.-B.; Xing, A.; Moon, B.P.; Koellhoffer, J.P.; Huang, L.; Ward, R.T.; Clifton, E.; Falco, S.C.; Cigan, A.M. Cas9-Guide RNA directed genome editing in soybean. Plant Physiol. 2015, 169, 960-970. [CrossRef]

232. Fan, D.; Liu, T.; Li, C.; Jiao, B.; Li, S.; Hou, Y.; Luo, K. Efficient CRISPR/Cas9-mediated targeted mutagenesis in Populus in the first generation. Sci. Rep. 2015, 5, 1-7. [CrossRef]

233. Zhang, B.; Yang, X.; Yang, C.; Li, M.; Guo, Y. Exploiting the CRISPR/Cas9 system for targeted genome mutagenesis in Petunia. Sci. Rep. 2016, 6, 1-8. [CrossRef]

234. Abdelrahman, M.; Al-Sadi, A.M.; Pour-Aboughadareh, A.; Burritt, D.J.; Tran, L.S.P. Genome editing using CRISPR/Cas9-targeted mutagenesis: An opportunity for yield improvements of crop plants grown under environmental stresses. Plant Physiol. Biochem. 2018, 131, 31-36. [CrossRef] [PubMed]

235. Mushtaq, M.; Bhat, J.A.; Mir, Z.A.; Sakina, A.; Ali, S.; Singh, A.K.; Tyagi, A.; Salgotra, R.K.; Dar, A.A.; Bhat, R. CRISPR/Cas approach: A new way of looking at plant-abiotic interactions. J. Plant Physiol. 2018, 224-225, 156-162. [CrossRef] [PubMed]

236. Ding, Y.; Li, H.; Chen, L.-L.; Xie, K. Recent advances in genome editing using CRISPR/Cas9. Front. Plant Sci. 2016, 7, 1-12. [CrossRef] [PubMed]

237. Ghosh, S.; Watson, A.; Gonzalez-Navarro, O.E.; Ramirez-Gonzalez, R.H.; Yanes, L.; Mendoza-Suárez, M.; Simmonds, J.; Wells, R.; Rayner, T.; Green, P.; et al. Speed breeding in growth chambers and glasshouses for crop breeding and model plant research. Nat. Protoc. 2018, 13, 2944-2963. [CrossRef] [PubMed] 